\title{
Sapiens modernus: The Reception of Dietrich of Freiberg in Berthold of Moosburg
}

\author{
Evan King \\ University College Dublin / Newman Centre for the Study of Religions
}

The importance of the Dominican master Dietrich of Freiberg (d. after 1310) for Berthold of Moosburg's Exposition on the Elements of Theology has long been noted, though the extent of this influence has been measured only gradually. ${ }^{1}$ Dietrich's influence touches nearly every aspect of the commentary: its doctrines of intellect, causality, time and eternity, cosmology, the theory of soul, the conception of contemplation and beatitude, ontology, natural philosophy, and theology. By my calculation, based on the table below, Berthold cites a text from Dietrich, on average, at least once per Proposition and takes, on average, at least two passages from him each time. The overall situation was succinctly described by Loris Sturlese over 30 years ago: "A catalogue of doctrines inherited by Berthold would equal an index of Dietrich's corpus. We will see that Berthold also cheated, at times. But the agreement with Dietrich goes so far and is thus so emphatic in the Exposition that this must be considered as a foundation for every interpretation of Berthold's work". ${ }^{2}$ This judgement has proven true for almost every study of particular doctrines in the Exposition. ${ }^{3}$ My aim here is to bring to light the deeper patterns of this reception.

* This article was completed within the context of the ERC Grant NeoplAT (CoG_771640).

1 The connection was first noted briefly by M. Grabmann, "Studien über Ulrich von Straßburg”, in Zeitschrift für katholiche Theologie 29(1905), p. 626, and E. Krebs, Meister Dietrich (Theodoricus Teutonicus de Vriberg). Sein Leben, seine Werke, seine Wissenschaft (Münster: Aschendorff, 1906), p. 5o. On Dietrich of Freiberg, see now K. Flasch, Dietrich von Freiberg. Philosophie, Theologie, Naturforschung um 1300 (Frankfurt am Main: Klostermann, 2007); L. Sturlese, "Dietrich von Freiberg", in A. Brungs, V. Mudroch, P. Schulthess (eds), Die Philosophie des Mittelalters, vol. 4. 13. Jahrhundert (Basel: Schwabe, 2017), p. 895-911.

2 L. Sturlese, Homo divinus. Philosophische Projekte in Deutschland zwischen Meister Eckhart und Heinrich Seuse (Stuttgart: Kohlhammer, 2007), p. 139.

3 See A. de Libera, La mystique rhénane. D'Albert le Grand à Maître Eckhart (Paris: Seuil, 1994), p. 326-384, with bibliography; T. Iremadze, Konzeptionen des Denkens im Neuplatonismus. Zur Rezeption der Proklischen Philosophie im deutschen und georgischen Mittelalter. Dietrich 
The overall pattern can be construed as a dialogue between ancients and moderns in Berthold's commentary. Dietrich is the exemplary figure of the modern master in confrontation with ancient wisdom. The pattern in Berthold's reception of his thought is an act of transposition and sublation. Berthold transplanted Dietrich's metaphysics, whenever possible, back into ancient soil; this is his consistent practice with most of his contemporary sources, e.g., Thomas of York, Albert the Great, and Ulrich of Strassburg. But there is also a striking element of duplicity or "cheating" in his use of Dietrich. This was not because Berthold believed his master's thought was incoherent; I intend to show that Berthold proceeded as if Dietrich's intellectual aims could be realized only by going back to an earlier golden age, and this is why I call it an act of sublation. In this gesture, Berthold profoundly transformed central elements of Dietrich's philosophical project. For Berthold, Dietrich's insights into the order of separate beings and their necessary interconnection were stated inadequately, tarnished by the same forgetting that affected all the "moderns" - one might call it the forgetting of what is beyond being.

As Dragos Calma has shown, Dietrich's copy of the Elements of Theology, which he used throughout his career, lacked at least four propositions. ${ }^{4}$ By contrast, Dietrich cited Augustine with great care, often supplying alternate systems of enumerating the chapters. But it seems he was not sufficiently concerned with the authority of Proclus to emend his copy of the Elements. A comparison with Dietrich's use of the Liber de causis has indicated that he preferred it to Proclus. ${ }^{5}$ As for Berthold, his sympathy and familiarity with three rare texts made this attitude inconceivable: Proclus' Three Works on Providence, the Sapientiale of Thomas of York, ${ }^{6}$ and the 12th-century paraphrase of Eriugena's Periphyseon called the Clavis physicae, which Berthold attributed to a "Theodorus, Abbot of Constantinople". Each of these established the fundamental doxographical alliance of Proclus and Dionysius. The

von Freiberg - Berthold von Moosburg - Joane Petrizi (Amsterdam: Grüner, 2004); M. Führer, S. Gersh, "Dietrich of Freiberg and Berthold of Moosburg", in S. Gersh (ed.), Interpreting Proclus. From Antiquity to the Renaissance (Cambridge: Cambridge University Press, 2014), p. 299-317; E. King, "Berthold of Moosburg on Intellect and the One of the Soul", in Dionysius 36(2018), p. 184-199; P. Hellmeier, "Der Intellekt ist nicht genug. Das proklische unum in nobis bei Berthold von Moosburg", in Philosophisches Jahrbuch 126/2(2019), p. 202-226.

4 D. Calma, Le poids de la citation. Étude sur les sources arabes et grecques dans l'ouvre de Dietrich de Freiberg (Fribourg: Academic Press, 2010), p. 277-278.

5 Calma, Le poids de la citation, p. 341-342, 371-375.

6 See the contributions of Fiorella Retucci and Loris Sturlese in this volume.

7 E. Ludueña, La recepción de Eriúgena en Bertoldo de Moosburg. Un aporte sobre la Escuela de Colonia (Saarbrücken: Publicia, 2013); E. King, "Eriugenism in Berthold of Moosburg's Expositio super Elementationem theologicam Procli", in D. Calma (ed.), Reading Proclus and 
result could not be overlooked. As Loris Sturlese has put it, for Dietrich, Proclus was "a diligent investigator" of the essential natural order of the cosmos, but for Berthold, he became "a divine man" and, in a sense, "a prophet" of "a philosophical revelation". "Thus the very letter of the Elements of Theology, each term in each Proposition, carried the weight of a luminous ancient wisdom. It was the commentator's task to adjust weaker modern eyes to that light. ${ }^{9}$

This paper has three parts: Part 2 presents the quantitative data of Dietrich's presence in the Exposition; Part 3 analyses some case studies of Berthold's critique and transformation of Dietrich's works; Part 4 develops a hypothesis about Berthold's use of a lost theological text from Dietrich.

\section{The Citations of Dietrich of Freiberg in the Exposition: Formal Analysis}

The table below presents the number of citations of Dietrich's works found in the commentary. ${ }^{10}$

the Book of Causes, Volume 1. Western Scholarly Networks and Debates (Leiden: Brill, 2019), p. 394-437.

8 Sturlese, Homo divinus, p. 143, 145.

9 Berthold of Moosburg, Expositio super Elementationem theologicam Procli, eds M.R. Pagnoni-Sturlese, L. Sturlese (Hamburg: Meiner, 1984), Prologus 21, p. 34, l. 974-975: Igitur cum Platone et Boethio bonum esse reor humilem theoricum obnixe lucem divinissimam votis supplicibus invocare [...]. All citations of the Expositio refer to the critical edition published in the Corpus philosophorum teutonicorum medii aevi. See Berthold of Moosburg, Expositio super Elementationem theologicam Procli. Propositiones 14-34, eds L. Sturlese, M.R. Pagnoni-Sturlese, B. Mojsisch (Hamburg: Meiner, 1986); Berthold of Moosburg, Expositio super Elementationem theologicam Procli. Propositiones 35-65, ed. A. Sannino (Hamburg: Meiner, 2001); Berthold of Moosburg, Expositio super Elementationem theologicam Procli. Propositiones 66-107, ed. I. Zavattero (Hamburg: Meiner, 2003); Berthold of Moosburg, Expositio super Elementationem theologicam Procli. Propositiones 108-135, ed. F. Retucci (Hamburg: Meiner, 2011); Berthold of Moosburg, Expositio super Elementationem theologicam Procli. Propositiones 136-159, ed. F. Retucci (Hamburg: Meiner, 2007); Berthold of Moosburg, Expositio super Elementationem theologicam Procli. Propositiones 160-183, eds U.R. Jeck, I.J. Tautz (Hamburg: Meiner, 2003); Berthold of Moosburg, Expositio super Elementationem theologicam Procli. Propositiones 184-211, ed. L. Sturlese (Hamburg: Meiner, 2014).

10 The works of Dietrich of Freiberg are cited according to the critical edition (Corpus philosophorum teutonicorum medii aevi). See Dietrich of Freiberg, Opera omnia, vol. 1. Schriften zur Intellekttheorie, ed. B. Mojsisch (Hamburg: Meiner, 1977); Dietrich of Freiberg, Opera omnia, vol. 2. Schriften zur Metaphysik und Theologie, eds R. Imbach et al. (Hamburg: Meiner, 1980); Dietrich of Freiberg, Opera omnia, vol. 3. Schriften zur Naturphilosophie und Metaphysik, eds J.-D. Cavigioli et al. (Hamburg: Meiner, 1983); Dietrich of Freiberg, Opera 
For the sake of simplicity, Berthold's citations of Dietrich are arranged in each column according to the volume of the critical edition of the Exposition, which in most cases (volumes 1, 5, 6, 7, and 8) correspond precisely or closely to natural divisions in the Elements of Theology. In each row of the table, the number outside the parentheses refers to the number of subsections in Berthold's commentary (such as: $2 \mathrm{~A}, 2 \mathrm{~B}, 2 \mathrm{C}$, etc.) where a citation of each text is found. The number in parentheses represents the total citations. For example, Proposition ${ }_{167} \mathrm{C}$ has been counted to include six citations for De intellectu et intelligibili, which would be represented by 1 (6). The total for that volume indicates that Berthold cited De int. in 16 different subsections of his commentary for a total of 40 citations. It is worthwhile keeping these two figures distinct, because the subsections of the Exposition correspond to Berthold's explanations of separate terms, doctrines, or arguments. These subsections are the most basic building blocks of the Exposition. Therefore, the number outside parentheses gives a sense of how the influence of each of Dietrich's treatises permeates the fundamental structure of the commentary. The number in parentheses reflects the use of a more artificial standard for counting a citation. These numbers are significantly lower than those one would reach by simply counting the entries in the indices of the critical edition, for two reasons. First, I do not count terms or phrases as citations, however characteristic Berthold's thorough appropriation and internalisation of Dietrich's philosophical terminology they may be. Furthermore, it would often be impossible to determine which

omnia, vol. 4. Schriften zur Naturwissenschaft, eds M.R. Pagnoni-Sturlese et al. (Hamburg: Meiner, 1985). Abbreviations: De acc. (De accidentibus, ed. M.R. Pagnoni-Sturlese, vol. 3); De anim. (De animatione caeli, ed. L. Sturlese, vol. 3); De cog. ent. (De cognitione entium separatorum, ed. H. Steffan, vol. 2); De cor. cael. (De corporibus caelestibus quoad naturam eorum corporalem, ed. L. Sturlese, vol. 2); De dot. (De dotibus corporum gloriosorum, ed. L. Sturlese, vol. 2); De elem. (De elementis corporum naturalium, ed. M.R. Pagnoni-Sturlese, vol. 4); De ente (De ente et essentia, ed. R. Imbach, vol. 2); De hab. (De habitibus, ed. H. Steffan, vol. 2); De int. (De intellectu et intelligibili, ed. B. Mojsisch, vol. 1); De intellig. (De intelligentiis et motoribus caelorum, ed. L. Sturlese, vol. 2); De ir. (De iride et de radialibus impressionibus, eds M.R. Pagnoni-Sturlese, L. Sturlese, vol. 4); De luce (De luce et eius origine, ed. R. Rehn, vol. 4); De magis (De magis et minus, eds R. Imbach, H. Steffan, vol. 2); De mens. (De mensuris, ed. R. Rehn, vol. 3); De misc. (De miscibilibus in mixto, ed. W. Wallace, vol. 4); De nat. contin. (De natura et proprietate continuorum, ed. R. Rehn, vol. 3); De nat. contr. (De natura contrariorum, ed. R. Imbach, vol. 2); De orig. (De origine rerum praedicamentalium, ed. L. Sturlese, vol. 3); De pot. (De ratione potentiae, ed. M.R. Pagnoni-Sturlese, vol. 3); De quid. (De quiditatibus entium, eds R. Imbach, J.-D. Cavigioli, vol. 3); De subiecto (De subiecto theologiae, ed. L. Sturlese, vol. 3); De sub. spir. (De substantiis separatis et corporibus futurae resurrectionis, ed. M.R. Pagnoni-Sturlese, vol. 2); De vis. beat. (De visione beatifica, ed. B. Mojsisch, vol. 1); Quaest. utrum in Deo (Quaestio utrum in Deo sit aliqua vis cognitiva inferior intellectu, ed. M.R. Pagnoni-Sturlese, vol. 3); Quaest. utrum sub. spir. (Quaestio utrum substantia spiritualis sit composita ex materia et forma, ed. B. Mojsisch, vol. 3). 
Prol.-13 14-34 35-65 66-107 108-135 136-159 16o-183 184-211 Total

\begin{tabular}{|c|c|c|c|c|c|c|c|c|c|}
\hline 1. De int. & $3(4)$ & $9(22)$ & $2(4)$ & $8(9)$ & $4(10)$ & $1(2)$ & $16(40)$ & $5(11)$ & $48(102)$ \\
\hline 2. De vis. beat. & $3(3)$ & $4(7)$ & $6(11)$ & $1(2)$ & $3(4)$ & $4(5)$ & $14(24)$ & $3(3)$ & $37\left(5^{8}\right)$ \\
\hline 3. De orig. & $2(2)$ & $5(13)$ & $2(3)$ & $7(11)$ & $3(5)$ & $1(2)$ & $2(3)$ & $1(1)$ & $23(40)$ \\
\hline 4. De anim. & $1(2)$ & $4(8)$ & $2(2)$ & $5(11)$ & & & $2(5)$ & $7(10)$ & $21(38)$ \\
\hline 5. De cog. ent. & $1(6)$ & $3(3)$ & $2(2)$ & $2(6)$ & & $1(1)$ & $5(9)$ & $1(2)$ & $15(29)$ \\
\hline 6. Quaest. & $1(2)$ & $1(2)$ & $5(7)$ & $4(16)$ & $1(3)$ & $1(1)$ & $1(7)$ & & $14(38)$ \\
\hline \multicolumn{10}{|l|}{ utrum in Deo } \\
\hline 7. De sub. spir. & & & & $5(9)$ & $1(6)$ & & & $5(10)$ & $11(25)$ \\
\hline 8. De mens. & & & $7(21)$ & $2(3)$ & & & & & $9(24)$ \\
\hline 9. De dot. & & & $1(1)$ & $1(2)$ & $1(1)$ & & & $5(7)$ & $8(11)$ \\
\hline 10. De pot. & & $2(6)$ & & $3(8)$ & & & $1(3)$ & & $6(17)$ \\
\hline $\begin{array}{l}\text { 11. De nat. } \\
\text { contr. }\end{array}$ & $1(8)$ & & & $2(11)$ & & $1(1)$ & & & $4(20)$ \\
\hline $\begin{array}{l}\text { 12. Quaest. } \\
\text { utrum sub. spir. }\end{array}$ & & & & $1(1)$ & & & & $3(7)$ & $4(8)$ \\
\hline 13. De cor. cael. & & $2(4)$ & & $2(3)$ & & & & & $4(7)$ \\
\hline $\begin{array}{l}\text { 14. De nat. } \\
\text { contin. }\end{array}$ & & & $4(6)$ & & & & & & $4(6)$ \\
\hline 15. De misc. & & & $1(1)$ & $1(1)$ & $2(3)$ & & & & $4(5)$ \\
\hline 16. De acc. & & $1(7)$ & $2(3)$ & & & & & & $3(10)$ \\
\hline 17. De elem. & & & & $2(6)$ & & & & & $2(6)$ \\
\hline 18. De intellig. & & & & & & & & $2(5)$ & $2(5)$ \\
\hline 19. De magis & & & $1(1)$ & $1(3)$ & & & & & $2(4)$ \\
\hline 2о. De luce & & & $2(4)$ & & & & & & $2(4)$ \\
\hline 21. De ente & $1(3)$ & & & & & & & & $1(3)$ \\
\hline 22. De ir. & & & $1(1)$ & & & & & & $1(1)$ \\
\hline 23. De quid. & $1(1)$ & & & & & & & & $1(1)$ \\
\hline 24. De subiecto & $1(1)$ & & & & & & & & $1(1)$ \\
\hline Total & $15\left(3^{2}\right)$ & $3^{1}(72)$ & $38(67)$ & $47(102)$ & $15(32)$ & $9(12)$ & $41(91)$ & $3^{2}\left(5^{6}\right)$ & $228(464)$ \\
\hline
\end{tabular}

of Dietrich's works they derive from (e.g., ens secundum speciem, intellectus in actu per essentiam, ens conceptionale). Secondly, when Berthold copied many lines from the same treatise in sequence, as he frequently did, I count separate citations only when he omitted two lines of his source or interpolated two lines of his own, since these were evidently deliberate editorial acts on Berthold's part. Finally, in compiling this table I have identified eight overlooked citations of Dietrich. ${ }^{11}$

11 Berthold of Moosburg, Expositio, ${ }_{17}$ E, p. 40, 1. 257-259 = Dietrich of Freiberg, De int., II.5.1, p. 149, l. 6-10; Berthold of Moosburg, Expositio, 42F, p. 63, l. 28o-p. 64, l. $288 \approx$ Dietrich of Freiberg, De vis. beat., 1.3.2 (7), p. 55, l. 56-63 and 1.3.2 (10), p. 56, 1. 8o-86; Berthold of Moosburg, Expositio, 121D, p. 106, 1. 50-63 = Dietrich of Freiberg, De vis. beat., 3.2.9.2 (4), 
The quantitative data allow us to draw a few conclusions. (a) Works. Berthold's familiarity with Dietrich's corpus was profound. In the Exposition, Berthold used every extant treatise by Dietrich except for De coloribus, De corpore Christi mortuo, De habitibus, and the short Quaestiones preserved as reportationes - so 24 out of 28 works. Of Dietrich's eight other works listed in the 14th-century Stams catalogue, which are no longer extant, we know that Berthold knew at least one, De entium universitate. ${ }^{12}$ He refers to this treatise in his glosses on Macrobius, which date to before $1323 .{ }^{13}$ It seems safe to conclude that, at one time or another, Berthold had all, or almost all, of Dietrich's known corpus available to him, and drew freely from these works as the text of the Elements required.

(b) Rank. Berthold made consistent use of De intellectu et intelligibili (102), which incidentally contains Dietrich's praise of Proclus as a "diligent investigator" (diligens indagator) of the order of nature. ${ }^{14}$ In a distant second we find De visione beatifica (58), followed by De origine rerum praedicamentalium (40), and De animatione caeli (38). Next come works that Dietrich explicitly structured according to the four fundamental levels of the cosmos described in Proposition 20 of the Elements of Theology: De cognitione entium separatorum and De substantiis spiritualibus et corporibus futurae resurrectionis. All of the treatises in the top eight places, with the exception of De origine rerum praedicamentalium, often proceed by reasoning about the hierarchical structure of the universe and/or the modes of cognition appropriate to these levels or maneries, which explains why Berthold would favour them when explaining the cosmology outlined in the Elements. Only after the works on intellect and cosmology do we get Dietrich's works on theology (De dot.), ontology (De pot.,

p. 88, l. 20-32; Berthold of Moosburg, Expositio, 158E, p. 186, l. 73-78 = Dietrich of Freiberg, De cog. ent., 49.2, p. 214, l. 100-105; Berthold of Moosburg, Expositio, 171A, p. 110, 1. 45-49= Dietrich of Freiberg, De orig., 4.25, p. 175, l. 241-245; Berthold of Moosburg, Expositio, 171A, p. 110, l. 49-5o = Dietrich of Freiberg, De orig., 4.25, p. 175, 1. 249-p. 176, 1. 251; Berthold of Moosburg, Expositio, 189F, p. 72, l. 138-140 $\approx$ Dietrich of Freiberg, De orig., 4.6, p. 169, l. $33-$ p. 170, l. 37 .

12 On the catalogues of Dietrich's works, see L. Sturlese, Dokumente und Forschungen zu Leben und Werk Dietrichs von Freiberg (Hamburg: Meiner, 1984), p. 134-136.

13 ms Basel, Universitätsbibliothek, F.IV.31, f. 2or. The gloss corresponds to Macrobius, Commentarii in Somnium Scipionis, I.17.5: QVOD QVIDEM TO PAN, ID EST OMNE, DIXERVNT. Pan enim non est aliud quam mundus ipse; nota de ratione universitatis ex tractatu magistri Theoderici qui intitulatur De entium universitate.

14 Dietrich of Freiberg, De int., I.4.1, p. 138, 1. 44-46: Distinguit autem idem Proclus quadruplicem rerum maneriem, in quibus singulis diligens indagator, prout fuerit de proposito suo, necesse habet quaerere proprias uniuscuiusque eorum operationes. 
De nat. contr., De acc., etc.), and natural philosophy (Quaest. utrum sub. spir., De cor. cael., etc.).

(c) Distribution. ${ }^{15}$ The highest distribution of citations by proposition is in 160-183, which primarily concern the intellect, followed by Propositions 14-34, on the four genera of the cosmos and essential causality. We also notice a decrease of citations between Propositions 108-159, which concern the primordial causes or gods (unitates, bonitates) and their providence. Incidentally perhaps, here one observes an increase in citations from Ulrich of Strassburg and Thomas of York.

(d) Explicit references. Only two of all the citations of Dietrich are explicit references, and both provide the title of Dietrich's treatise: magisterTheodoricus prima parte tractatus De animatione caeli $(107 \mathrm{~A})$; magister Theodoricus tractatu De natura oppositorum cap. 44 (143O). Both attributions are correct. By comparison with other contemporary authors used in the Exposition, apart from the appearance of their names in two tables of authorities that accompany the commentary, we find only one explicit reference to Albert the Great (118A), one to Thomas Aquinas (204A), and zero for Thomas of York and Ulrich of Strassburg, which is hardly representative of the degree to which Berthold relied on their work. Nevertheless, in these limited cases there appears to be a pattern. The explicit mentions of Albert and Thomas occur after Berthold cites a lengthy passage that conveys their final determination about a classic topic in philosophical theology: how a plurality of ideas is in God (118A) and whether the rational soul is created de novo or is transmitted through the seed (204A). Berthold's decisions to cite Dietrich explicitly coincide with passages in which he presents an argument from Dietrich that he endorses and when this argument makes a valuable correction to an older authority, either Avicenna and Algazel (107A) ${ }^{16}$ or Alhazen (143O).

(e) Indirect citations. Most of Berthold's citations of Dietrich are implicit (quidam or alii $)^{17}$ or tacit. Often the implicit citations occur when Dietrich's argument is compared with a different view from another more contemporary

15 The averages per proposition by СРтмA volume, which roughly correspond to the division of the larger themes and subject matter of the Elements are: 1-13: 1.15 (2.46); 14-34: 1.55 (3.60); 35-65: 1.27 (2.30); 66-107: 1.15 (2.49); 108-135: o.55 (1.19); 136-159: o.35 (0.48); 160-183: 1.70 (3.78); 184-211: 1.15 (2.04). The proportion for ET 1-13 decreases if we include the three prefaces, which contain only three citations.

16 They are unnamed at $107 \mathrm{~B}$ but are named in the parallel passage at $185 \mathrm{~B}$.

17 For example, $3 \mathrm{~A}$ (De anim.?); $7 \mathrm{C}$ (De vis. beat.) $21 \mathrm{I}$ (De cog. ent.); $43 \mathrm{~F}$ (De int.); $74 \mathrm{~B}$ (De orig.); 88A (De mens.); 104E (De mens.); 105B (De int.); 106F (De anim.); $111 \mathrm{~B}$ (De int.); 129A (De misc.); 129A (De sub. spir., twice); 133E (De anim.?); 183A (De vis. beat.?); 190A (De int. and Devis. beat.). 
author, like Ulrich, ${ }^{18}$ or where Berthold disagrees with the view advanced by Dietrich, because it either conflicts with the Platonists or inadequately captures a Platonic doctrine, as we see in the case studies that follow.

\section{3}

\section{Case Studies}

Three instances of Berthold's reception of Dietrich are particularly illustrative: the doctrine of transcendentals, the theory of time and eternity, and the doctrine of causality. The first is foundational for the other two. As is clear to contemporary readers of his commentaries on Propositions 1 and 11, Berthold used texts from Dietrich when he presented a doctrine of "the transcendentals" that he attributes to Aristotle. ${ }^{19}$ At other times, Berthold used different texts from Dietrich to present both sides of the Plato-Aristotle divide. A salient example of this is when he contrasts the "Platonic" notion of a "metaphysical" genus as a level of reality defined by its natural place in the cosmic hierarchy (a maneries), ${ }^{20}$ with the "Aristotelian" sense of a metaphysical genus that is described using the De origine rerum praedicamentalium. ${ }^{21}$ I believe we should understand this two-sidedness as Berthold's redoubling of Dietrich's own characteristic critique against himself. Dietrich had criticized those who import imaginative and logical abstractions into metaphysics (the communiter loquentes), and Berthold subjected the Aristotelian metaphysics of being to the same criticism, which implicated Dietrich. For Berthold, being (ens) is prior only from the point of view of logical abstraction, and only the Platonic metaphysics of the Good is adequate to the reality beyond our abstractions.

The second and third cases focus on the only two passages where Berthold discusses the views of his contemporaries (moderni). Both cases illustrate how Berthold subordinated Dietrich's "contemporary" views to ancient Platonism. This occurs in two different ways: in the propositions on time and eternity, Berthold takes many essential doctrines from Dietrich's theory of time and eternity in De mensuris, but explicitly decides to restrict Dietrich's theory

18 For example, Berthold of Moosburg, Expositio, 59C, p. 166, 1. 128-p. 168, l. 175; Berthold of Moosburg, Expositio, 185B, p. 19, l. 171-172.

19 Berthold of Moosburg, Expositio, 1A, p. 74, l. 109-112: Et per consequens unum secundum [Aristotelem] et multum proprietates entis in eo, quod ens, erunt transcendentia, quarum esse etiam non est extra animam, quamquam secundum intellectum sint posteriora ente, utpote quorum unum addit super ens indivisionem, aliud vero divisionem sive distinctionem. On this characteristic theme of Dietrich's thought, see D. Calma, "Maneries", in I. Atucha et al. (eds), Mots médiévaux offerts à Ruedi Imbach (Porto: FIDEM, 2011), p. 433-444.

21 Berthold of Moosburg, Expositio, 135K-L, p. 227, l. 119-p. 229, l. 289. 
because it does not conform to the Platonic truth. In the third case, on causality, we observe the reverse: Berthold elaborates Dietrich's theory of three kinds of causes in order to align it with the Platonic theory of the five kinds of causes.

\subsection{Case 1: Being and Goodness (Critique)}

Berthold attributed to Aristotle a full-fledged doctrine of the transcendentals. ${ }^{22}$ The Aristotelian position, as Berthold presents it by tacitly borrowing the words of Dietrich of Freiberg, is that being (ens) is the most formal and primary of all intentions, and unum, verum, and bonum are logically derivative of being because they are resolvable into it. ${ }^{23}$ Berthold goes behind this position to address what he takes to be its flawed assumption, namely, that act always determines potency. ${ }^{24}$ According to Berthold, Plato acknowledged the validity of this approach relative to physical phenomena, where form always determines matter, but realized that their relation was reversed among the separate substances and the first principles, where potency is a limitation of active causal power. ${ }^{25}$ Following Aristotle's reasoning, however, we must maintain that diversity or multitude only arise from the most indeterminate and potential. Starting out from this, the Aristotelian way then posits that the first diversity arises as a form of an opposition in the relationship between privation and possession (habitus), which is reducible to the relation of potency and act, which is finally reducible to the logical opposition of negation and affirmation in a subject. ${ }^{26}$ On the basis of these assumptions, Berthold then gives a lengthy, if tacit, summary of Dietrich of Freiberg's derivation of the other transcendentals from ens by unfolding their notions from the foundational opposition of affirmation and negation.

Berthold's Aristotle, from a historical point of view, is of course a remarkable invention. In some sense his portrait is compatible with those of earlier Neoplatonic commentators who advocate for an ultimate harmony of Plato and Aristotle, provided the Aristotelian philosophy is restricted to the sublunary world. With Berthold, however, the emphasis falls on the discord at the

22 See J. Aertsen, Medieval Philosophy as Transcendental Thought. From Philip the Chancellor (ca. 1225) to Francisco Suárez (Leiden: Brill, 2012), p. 545-553.

23 Berthold of Moosburg, Expositio, 11A, p. 185, l. 23-p. 186, 1. 4 O.

24 Berthold of Moosburg, Expositio, 1A, p. 72, 1. 53-54: Secundum Aristotelem autem VII Metaphysicae suae actus separat et distinguit [...].

25 Berthold of Moosburg, Expositio, 1A, p. 73, 1. 90-93: Plato vero alia via incedit circa multitudinis originem, qui, licet concedat distinctionem esse formalem causam multitudinis, tamen actus secundum eum non ubique, hoc est in tota rerum universitate, distinguit nisi in solis materialibus.

26 Berthold of Moosburg, Expositio, 1A, p. 72, l. 58-62. 
level of their metaphysics and the need for a total reversal in first principles. It is important to reflect on the underlying motivations for this. For him, it seems a danger lurks in the metaphysics of being that threatens to occlude human nature and its proper relation to the divine. In short, an exclusively physicalist view of the origin of diversity ends up producing a strictly intra-mental or logical metaphysics: we make an imaginative reduction to the primary substratum, prime matter, and from there have recourse to the first principles of logic, the principle of non-contradiction, to account for the principles of diversity and multitude. These principles, however, have lost all bearing on the world outside the mind. Berthold uses a remark from Averroes as verification that the Aristotelians are willing to admit that these transcendental determinations do not have any being outside the soul. ${ }^{27}$ Such an outlook must be subject to the verdict of Dionysius: the unlearned are sealed off among beings and believe there is nothing that is supersubstantial beyond. ${ }^{28}$ Perhaps Berthold believes that these tendencies were coming to fruition among some of his contemporaries in the late 1310s in Oxford. In any event, he shares the view of Proclus, Dionysius, and Boethius that individuals tend to disperse themselves in the physical world, and that what is beyond being is therefore hidden from our everyday awareness. ${ }^{29}$ Platonic theology resists this imaginative impulse and prepares its practitioner to know and be united with the divine realities themselves, which are measured in terms of a causal influence that is independent of the activity of our minds. ${ }^{30}$ Platonism, therefore, is the corrective of both a

27 Berthold of Moosburg, Expositio, 1D, p. 77, l. 218-219; Berthold of Moosburg, Expositio, 11A, p. $186,1.43-47$.

28 Berthold of Moosburg, Expositio, 71D, p. 35, l. 123-127, directed against the Liber de causis, proposition IV.

29 Cf. Berthold of Moosburg, Expositio, Prol. 17, p. 27, 1. 724-726: Donec autem circa ea, quae deorsum, volvimur, increduliter habemus circa haec. Cf. Berthold of Moosburg, Expositio, Prol. 15, p. 23, l. 583-587: [...] quae sunt corpus, anima, intellectus et unum sive unitas. De quorum ultimo, quia prima tria manifesta sunt, sic dicit Proclus [...]: "Et enim nobis (scilicet hominibus) iniacet aliquod secretum unius vestigium, quod et eo, qui intellectus, est divinius". Cui concordat Dionysius [...].

30 Another important source for Berthold was the Byzantine commentator Eustratius, and his arguments against Aristotle's criticism of the Good in the Nicomachean Ethics, insofar as Eustratius distinguished between logical universals, produced by the mind, and universals of separation, which Berthold also calls "theological universals", that are beyond the mind. See F. Retucci, "Tommaso di York, Eustrazio e la dottrina delle idee di Platone", in A. Beccarisi, R. Imbach, P. Porro (eds), Per perscrutationem philosophicam. Neue Perspektiven der mittelalterlichen Forschung. Loris Sturlese zum 6o. Geburtstag gewidmet (Hamburg: Meiner, 2008), p. 79-111. See Berthold of Moosburg, Expositio, 1A, p. 74, l. 98-102; Berthold of Moosburg, Expositio, 11A, p. 186, 1. 56-59. 
contemplative failure and a baleful lack of rational self-criticism at the heart of the metaphysics of being.

Anyone familiar with Dietrich of Freiberg will feel that Berthold is somehow dealing unfairly with his source here. Perhaps no philosopher of his time was more critical of reified, imagistic thinking in metaphysics than Dietrich, as Kurt Flasch in particular has emphasized by pointing precisely to Dietrich's exegesis of Aristotle himself, and especially the Stagirite's doctrines of substance and intellect. ${ }^{31}$ Dietrich recognized perfectly well that the move from physics to metaphysics entailed a shift in perspective characterized by the abandonment of extrinsic efficient and final causal explanations. Furthermore, his dynamic view of intellectual substance was founded firmly on the De anima and Metaphysics XII. Berthold of course was fully aware of this. As we see in his extension of Dietrich's critiques of the communiter loquentes, below, he intended, if anything, to go further in this direction. But it was perhaps Dietrich's own endorsement of the metaphysics of being and his characteristic doctrine of the possible intellect, which "effects the universality in things", 32 that made it necessary for Dietrich's own works to be played off against one another. ${ }^{33}$

In other words, Berthold judged Dietrich's metaphysics to be on the cusp of the truth: it was fundamentally correct in its aspirations but flawed in its expression. Only one further step was needed, which was to restore it to the ancient philosophical soil that would rearticulate those ambitions, and thus give them a form in which they could be realized. He fundamentally endorsed the principle Dietrich took from Aristotle, "each thing exists for the sake of

31 Flasch, Dietrich von Freiberg, p. 119: "Dietrichs origo-Analyse beansprucht, zugleich Theorie der Wissenschaften zu sein. Sie bestimmt nicht nur die Aufgabe der Metaphysik neu; sie faßt auch das Gebiet der Physik strenger und zieht die Grenze zwischen Logik und Metaphysik schärfer. [...] Wenn Dietrich ein Revolutionär war, dann ein konservativer Revolutionär, denn er wollte nur herausstellen, was er in der Philosophie der Peripatetiker enthalten fand und es gegen waltende Banalisierungen verteidigen." And p. 200: "Diese Intellekte sind anders als Dinge. Sie zu begreifen, erfordert eine Reform des dingorientierten Denkens." Also, p. 226: "Befreien wir unseren Selbstbegriff von verdinglichenden Vorstellungen und erneuern wir unser Verständnis des christlichen Glaubens."

32 Berthold of Moosburg, Expositio, 11A, p. 186, l. 41-42: Ens autem sic acceptum est communissimum in se communitate abstractionis, quam facit intellectus, qui efficit universalitatem in rebus. Cf. Dietrich of Freiberg, De orig., 3.8, 4.1, 5.33; Dietrich of Freiberg, De ente, I.1.2; Dietrich of Freiberg, De quid., 1.3.

33 See, for example, $16 \mathrm{D}$ and $177 \mathrm{H}$. Both passages appeal to Dietrich's distinction of abstraction, which is the work of reason, and separation, which is the work of nature. In 16D, Berthold uses De origine on intellect to describe abstraction, and De animation caeli to describe the condition of separate substances. In $177 \mathrm{H}$, he uses De intellectu on logical universals, followed by De cognitione on separate universals. 
its own operation". ${ }^{34}$ For Berthold, however, this could be best justified if one acknowledged the priority of the Good. In this view, bonum and unum are the most formal of all intentions if we consider what makes a reality an organized totality, be it a singular thing, an entire series, or the whole cosmos, by ordering it relative to all other things and/or within itself. In other words, placing bonum before ens compels the mind to seek first the concrete, dynamic, and essential order of the totality. Statements like the following from Dietrich anticipate this point of view:

An isolated essence by itself does not possess the characteristic of the good, nor does it pertain to the real order of the universe insofar as it is a single whole, complete in species and in parts. It is a characteristic of this order of the universe that one thing flows into another by means of some active power. ${ }^{35}$

The best way to make sense of this duplicity is to say that Berthold was in fact thoroughly shaped by Dietrich's way of thinking, but his reading of Proclus, Dionysius, and Eustratius had made him aware of the instability in the metaphysics of being that inherently would indulge the human soul's propensity to turn itself away from the realities above it and insulate itself from the good they bestow. Therefore, he recast the divide between the material and immaterial orders along Platonic and Aristotelian lines.

This critical move inevitably led to distortions of Dietrich's thought, especially relative to his noetics. Burkhard Mojsisch has pointed to an important passage in 168B-D, where Berthold downgrades the constitutive power of the possible intellect. When tacitly citing Dietrich on the way the intellect constitutes its object "conceptionally" (conceptionaliter), Berthold explains that this means "conceptually" (conceptive) or "intentionally", such that what is thus constituted has being only in the mind ${ }^{36}$ Similarly, Mojsisch observed, nowhere in Berthold do we find Dietrich's strong affirmation that the agent

\footnotetext{
34 Aristotle, De caelo II.3, 286a8-9.

35 Dietrich of Freiberg, De int., I.10.3, p. 143, l. 22-25: Absoluta enim essentia secundum se non habet rationem boni nec est de reali ordine universi, inquantum est unum totum perfectum specie et partibus, de cuius ordinis ratione est, ut una res fluat in aliam aliqua virtute activa. Cf. Berthold of Moosburg, Expositio, 6B, 44A, and 131D.

36 B. Mojsisch, "Die Theorie des Intellekts bei Berthold von Moosburg: zur Proklosrezeption im Mittelalter", in Th. Kobusch, B. Mojsisch, O. Summerell (eds), Selbst - Singularität Subjektivität. Vom Neuplatonismus zum Deutschen Idealismus (Amsterdam: Grüner, 2002), p. $175^{-184 .}$
} 
intellect knows the first principle in the manner of the principle itself. ${ }^{37}$ But we should recognize that both changes follow from a coherent standpoint. For Berthold, it is only the unum animae, which places us outside ourselves and beyond the limits of our knowing, that could know in the manner of the principle, and it is only through that principle that the human is placed in any constitutive or providential relation to the world.

\subsection{Case 2: The Measures of Time and Eternity (Restriction)}

The next case studies show the two opposed ways Berthold reconciled the rational insights of the modern master with the authority of the Platonists. The first comes from the propositions on time and eternity. Here, Berthold extensively uses Dietrich's De mensuris, which contains a complex account of the different measures of temporal and eternal activity. In total, Dietrich posits five kinds of measurement corresponding to five cosmic maneries: God (superaeternitas); the intelligences, "if such beings exist" (aeternitas); angels (aevum); celestial bodies (aeviternitas); sublunary beings (tempus). ${ }^{38}$ There are additionally two kinds of measures relating to things whose essence is subject to change and succession: motion, which applies to material things, and "time consisting from indivisibles" (tempus constans ex indivisibilibus), which relates to changes in spiritual substances. ${ }^{39}$ These distinctions arise when entities are ranked according to four intrinsic criteria: (1) the mode and property of a thing's substantial perfection; (2) whether there is variation of its substance, and what this is; (3) whether it has a beginning and an end, and what these are; (4) the presentness (praesentialitas) or mode of presentness belonging to its existence. ${ }^{40}$ After citing passages from De mensuris 21 times between Propositions 49 and 54, and presenting these principles and conclusions as those of the more subtle contemporary sages (moderni sapientes et subtiliores), Berthold concludes with the following:

Although what has just been said seems to have been said reasonably [rationabiliter dicta], notwithstanding this, in truth, according to the Platonists, there are in fact only two measures. ${ }^{41}$

37 Dietrich of Freiberg, De vis. beat., 1.2.1.3 (2), p. 44, l. 9-p. 45, l. 20; Dietrich of Freiberg, De int., II.40.3, p. 177, l. 72-77.

38 Dietrich of Freiberg, De mens., 2.7-32, p. 218, l. 106-p. 222, l. 246.

39 Dietrich of Freiberg, De mens., 2.33-48, p. 222, l. 247-p. 225, l. 339.

40 Dietrich of Freiberg, De mens., 2.6, p. 218, 1. 98-105.

41 Berthold of Moosburg, Expositio, 54G, p. 131, l. 95 and 54H, p. 133, l. 162-164: De primo notandum, quod moderni sapientes et subtiliores advertentes ea quattuor, quae ad assignandum rebus proprias mensuras requiruntur, [...] soliti sunt septem mensurarum differentias 
Berthold's procedure here understandably has frustrated some of his modern commentators. ${ }^{42}$ Nevertheless, it is important to appreciate the tensions navigated by Berthold as he proceeds in accordance with the principles of his project.

Berthold finds himself in a difficult position. His sympathy with Dietrich's arguments is clear throughout Propositions 49-54. He even embellishes his summaries of De mensuris with concepts characteristic of Dietrich's thought. For example, he contrasts the use of the four intrinsic criteria, mentioned above, with the approach of the communiter loquentes, who reason about the measures of time only according to extrinsic considerations arising in the domain of voluntary providence. ${ }^{43}$ The textual basis for interpolating these notions is clear, although he combines two groups mentioned by Dietrich into one. Dietrich had mentioned the communiter agentes who assume that the mode of a measure must equal the measure of duration. Thus, they consider only whether a thing's duration has a beginning and/or an end: God, who has no beginning or end, is measured by eternity; created, incorruptible creatures, who have a beginning but no end, are measured by the aevum; generable and corruptible creatures are measured by time. There are others, Dietrich added, who adopt only a comparative approach, in which beings are compared either to the whole universe, to God, or to one another. This yields four measures: eternity is the measure of God's duration, because he precedes the existence of the universe; the universe is measured by sempiternity, through a comparison with eternity; particular beings are measured by perpetuity, because they receive their being at a certain time and last as long as the sempiternal universe; finally, things that come before and after one another are said to be in the past or in the future relative to one another, and these are measured by temporality. For Dietrich, both ways of assigning these measures are extrinsic to the properties of the substance of things (extra proprietatem substantiae rerum) and are received, as it were, from the outside (quasi extrinsecus acceptus). ${ }^{44}$ From the perspective of voluntary providence, which Berthold invokes here,

assignare. [...] Circa secundum advertendum, quod licet ea, quae iam dicta sunt, rationabiliter dicta videantur, tamen salva gratia eorum, in veritate secundum Platonicos secundum rem non sunt nisi duae mensurae, aeternitas videlicet et tempus.

C. Steel, "The Neoplatonic Doctrine of Time and Eternity and its Influence on Medieval Philosophy", in P. Porro (ed.), The Medieval Concept of Time. Studies on the Scholastic Debate and its Reception in Early Modern Philosophy (Leiden: Brill, 2001), p. 3-32, at p. 29. Berthold of Moosburg, Expositio, 52C, p. 121, l. 165-p. 122, l. 181. Berthold's remarks about the communiter loquentes and voluntary providence summarise Dietrich of Freiberg, $D e$ mens., 2.1-3.

Dietrich of Freiberg, De mens., 2.3, p. 217, l. 73-78. 
the consideration of the nature of a thing is secondary to extrinsic factors; for example, angels act in the world to serve God's voluntary providence that certain individuals will be saved. ${ }^{45}$ What a nature is in itself, essentially and universally, is assumed by voluntary providence, but does not strictly belong to its purview. ${ }^{46}$ Problems arise when the extrinsic scruples of voluntary providence encroach upon the intrinsic reasoning about natures. So, for instance, both models here either assume the creation of the world in time or move directly from God to the angels. Accordingly, the entities that populate either picture do not include the separate intelligences - "if they exist", as Dietrich cautions. As far as theoretical reason is concerned, what must come first is the intrinsic, per-se consideration of the realities themselves, their essence and their order, which proceeds according to rational patterns of symmetry and proportion. For Dietrich, Proclus' excellence in this reasoning is what made him the diligent investigator (diligens indagator) into the order of nature. It is important to note that Berthold praises the reasoning of the moderni sapientes as being "more subtle" (subtiliores), which suggests that this intrinsic consideration of natural providence is in fact more difficult to attain; indeed, our reason easily descends back into the imagination that specializes in viewing things extrinsically. ${ }^{47}$ Thus we see why Berthold was so sympathetic to these arguments, but also why scruples of another kind forced him to curtail their validity. For Berthold, these subtle arguments agree with the approach followed by the Platonists and yet they must ultimately yield to the dogmatic authority of the best of the ancient philosophers Plato and Proclus.

\subsection{Case 3: The Three Levels of Causes (Elaboration)}

Berthold takes the opposite approach to Dietrich's doctrine of the three levels of causes, namely, essential, substantial, and accidental causes. ${ }^{48}$ Whereas the previous example demanded a truncation of Dietrich's theory, this required elaboration. Berthold borrowed this doctrine of causes repeatedly, though the most sustained discussion appears in Proposition $7 \cdot{ }^{49} \mathrm{He}$ identifies this

45 Dietrich of Freiberg, De anim., 20.6, p. 31, l. 109-113.

46 Dietrich of Freiberg, De sub. spir., p. 319, l. 26-p. 320, l. 29; Dietrich of Freiberg, De vis. beat., 4.3.2 (4), p. 114, l. 16-21.

47 One of the two explicit mentions of Dietrich in the Expositio praises him with the same terms for an argument about mediation that is faithful to the patterns of symmetrical reasoning. See Berthold of Moosburg, Expositio, 107A, p. 247, 1. 6o-62: Ubi considerandum, quod dictis magister subtilissime, realissime concludit caelum esse animatum, sed non dat medium continuativum inter intellectuales hypostases et corpora caelestia, quod hic quaeritur, sicut patet, quae sunt extrema.

48 Dietrich of Freiberg, De vis. beat., 3.2.9.4, p. 9o, l. 2-p. 93, l. 104.

49 See also Berthold of Moosburg, Expositio, ${ }_{25} \mathrm{C}, 34 \mathrm{C},{ }_{51} \mathrm{~A},{ }_{72} \mathrm{C}, 75^{\mathrm{A}}$, and ${ }_{104 \mathrm{D}}$. 
Proposition as one of the two foundations of the entire project. This is because it is the first devoted principally to the Good. Having defended the primacy of the Good with arguments from the Timaeus, Dionysius, and Augustine in $7 \mathrm{~A}$, Berthold outlines the various kinds of productive causes. In $7 \mathrm{~B}$, he gives a fivefold division: the superbonum (God), the superessential goods, the essential causes, substantial causes, and accidental causes. After just over 100 lines of explanation, he then adds in ${ }_{7} \mathrm{C}$ :

However, it should be considered that certain moderns [quidam moderni] only distinguish three kinds of productive [principles] according to the three kinds of agent cause, namely, essential, substantial and accidental. ${ }^{50}$

He then gives a succinct summary of this "contemporary" position using two texts from Dietrich, De cognitione entium separatorum 75.1-76.6 and De animatione caeli $7.1-5$, which yields this threefold division. Essential causes act spontaneously in virtue of their essence, and therefore their effect is an essence in turn. Each cause is a being existing as a species (ens secundum speciem) that is immutable, and so is its effect. For Dietrich, the separate intelligences operate like this. Substantial causes, which act from their own substance, bring their effect into being out of the potency of material principles. Dietrich would identify these with the heavenly souls and the celestial bodies, whose effects are the substances of the sublunary world. Finally, accidental causes act by way of accidental features, like fire that acts by heat. The effect, in turn, is an accidental change, for example, being heated.

If we look back to the fivefold division proposed by Berthold in ${ }_{7} \mathrm{~B}$, there appears to be no significant difference between Berthold's highest three levels and Dietrich's essential cause. All of them act spontaneously and presuppose nothing before bestowing their effect. The difference seems to be one of vocabulary and precision: "essential, substantial, and accidental productive principles are less properly called [productive] and truly are less productive than superessential productive principles", while "superessential productive principles are called [productive] and are productive by analogy to the first productive principle as such". ${ }^{51}$ Therefore, the advantage of Berthold's

50 Berthold of Moosburg, Expositio, 7 C, p. 148, 1. 365-368: Et licet haec sufficiant de proposito, tamen considerandum est, quod quidam moderni solum distinguunt triplex genus productivorum secundum triplex genus causae agentis, essentialis videlicet, substantialis et accidentalis.

51 Berthold of Moosburg, Expositio, 7 C, p. 147, l. 336-p. 148, l. 338 and p. 148, 1. 351-353: inter iam enumerata productiva tam essentialia quam etiam substantialia et accidentalia minus proprie et vere sunt ut dicuntur productiva superessentialibus productivis. [...] Sola igitur 
more elaborate scheme is simply that it arranges causes according to modalities of goodness, and thus separates the unbounded creative causality of the Good, which calls all things into being, from the more determinate, qualified productive causality of the gods, and the more restricted causality of the many principles beneath the gods. ${ }^{52}$

Comparing his borrowings from Dietrich in ${ }_{7} \mathrm{C}$ to the original texts, it becomes clear that Berthold modifies his source in order to make it seem like this more complex structure was latent in the "contemporary" doctrine of essential causes..$^{53}$ Berthold thus gives the impression that the moderns come so far, but their intentions can be fully realized only by returning to the metaphysics of the Good articulated by the best of the ancient Platonists. ${ }^{54}$

Berthold thus interpolates Proclean structures into Dietrich's doctrine of creation and determination because it is consistent with that metaphysics of the Good and, again, because the authority of the Platonists must prevail. For the same reason, in his citation of De animatione caeli, Berthold omits a very significant caveat from Dietrich's text. After describing God's creative causality, Dietrich had gone on to add:

superessentialia et superbonum productiva stant in vera et propria ratione productivorum, licet ipsa superessentialia dicantur et sint productiva in analogia ad simpliciter primum productivum.

$5^{2}$ Berthold of Moosburg, Expositio, 7 B, p. 146, 1. 270-p. 147, l. 316.

53 Berthold of Moosburg, Expositio, 7C, p. 15o, 1. 427-p. 151, l. 445, with the modifications of Dietrich of Freiberg, De anim., 7.1-5 in bold: Ex praemissis colligitur secundum eos, quod sola causa essentialis dicitur et est causa productiva, a qua entia per suas essentias emanant modo simplici, quia non per motum vel quamcumque transmutationem, sed per simplicem defluxum totalis essentiae rei sic procedentis et hoc vel totaliter vel secundum determinatum modum, ut ex dictis apparet. In talis autem entis constitutione in esse attenditur simplicitas modi productionis non solum ex parte principii productivi-quod est ens ut simpliciter et ex hoc proprium modum principiandi effective habet simplicem et propter hoc sine motu et transmutatione -, verum etiam ex parte causati seu producti huic modo producendi active correspondet passive quidam proprius modus simplicitatis, quia tale productum vel non producitur ex aliquo subiecto - quale est omnis effectus, ut est solum prime productivi simpliciter, cuiusmodi est prime bonum -, vel, si producitur ex aliquo subiecto, hoc tamen subiectum quasi recipiens et intentio ipsum determinans ramanet ut res una, et sic secundum totalitatem sui in esse constituitur, licet non totaliter, cum solum prime productivum, cui etiam summus modus producendi competit, quia agit non solum non praesupponendo aliquod subiectum, ex quo vel in quod agat, sed etiam non praesupponendo actionem cuiuscumque prioris vel altioris virtutis, qua sua actio figatur et fundatur in producendo [...].

54 For a similar case, this time an extension of Dietrich's notion of "proceeding as an image" (procedere ut imago) to what is above intellect, see Berthold of Moosburg, Expositio, 29B, $58 \mathrm{~A}, 70 \mathrm{C}, 83_{3} \mathrm{~B}, 109 \mathrm{~A}, 125 \mathrm{D}, 131 \mathrm{D}, 145^{\mathrm{B}}$, and $185^{\mathrm{E}}$. 
But if there are other substances, which the curiosity of the philosophers asserts and which they call intelligences [...] these, I say, according to these philosophers, would be the principles of beings without presupposing a prior subject from elsewhere, but would presuppose the action and power of the first and higher principle. ${ }^{55}$

Dietrich was not the first to use these caveats when referring to the separate intellects; a passage from Siger of Brabant may be interpreted along these lines. ${ }^{56}$ But with Dietrich they became a matter of habit: there are over 40 such expressions in his work. ${ }^{57}$ It seems extremely important that Dietrich was always careful to make these cautionary remarks and that Berthold always omitted them and never spoke in these hypothetical terms himself. ${ }^{58}$ This reflects his fundamentally different view of pagan philosophical authority. In what follows I will argue that this difference extends down to the very roots of Berthold's conception of theology itself which, I believe, he derived from Dietrich and, following his consistent practice, developed in a new direction: Berthold unifies the orders of natural and voluntary providence, which Dietrich had used to separate philosophical and revealed theology, in Platonism as such.

55 Dietrich of Freiberg, De anim., 7.5, p. 18, 1. 67-p. 19, l. 75: Si autem essent aliae substantiae, quas curiositas philosophorum asserit et intelligentias vocant, quarum quaelibet secundum eos est intellectus in actu per essentiam, huiusmodi, inquam, essent secundum dictos philosophos principia entium non supposito aliunde aliquo subiecto, supposita tamen actione et virtute prioris et altioris principii, in cuius virtute et actione fundarentur et figerentur earum propriae actiones; et ideo non essent creatrices, quamvis entia secundum totas suas essentias ab ipsis procederent, modo tamen inferiore, quam sit ille, quo procedunt a primo omnium principio.

$5^{6}$ Siger of Brabant, Quaestiones in Metaphysicam, ed. A. Maurer (Louvain-la-Neuve: Éditions de l'Institut supérieur de philosophie, 1983), lib. III, q. 5, p. 83, l. 15-17: Nulla autem istarum viarum potest probari quod substantiae separate, si plures sint, habeant causam aliquam, nec etiam quod non habeant ex hoc quod aeternae sunt.

57 Dietrich of Freiberg, De cog. ent., 1.3-4, 2.3, 3.1, 5.2-3, 14.1, 27.2-3, 36.2, 37.1, 37.8, 39.2, 39.4, 44.9, 86.6; Dietrich of Freiberg, De sub. spir., 1.1, 1.3, 1.5, 2.2, 6.2, 9.1, 16.1, 18.2, 19.3, 23.4, 28.4; Dietrich of Freiberg, De vis. beat., 3.2.9.2.4, 3.2.9.8.1, 4.2.1.14; Dietrich of Freiberg, De orig., 1.14, 3.37; Dietrich of Freiberg, De int., II.34.1, III.25.1, III.30.2; Dietrich of Freiberg, De anim., 7.5, 9.1, 11.4, 15.1; Dietrich of Freiberg, Quaest. utrum in Deo, 1.1.4, 1.3.4; Dietrich of Freiberg, De mens., 2.11, 2.43, 8.3; Dietrich of Freiberg, De dot., 24.5; Dietrich of Freiberg, De acc., 8.2.

$5^{8}$ Berthold of Moosburg, Expositio, 44E, p. 77, l. 154-161, citing Dietrich of Freiberg, De acc., 8.2, p. 63, l. 97-p. 64, l. 104; Berthold of Moosburg, Expositio, 69B, p. 21, 1. 33-36, citing Dietrich of Freiberg, De sub. spir., 28.4, p. 327, l. 25-28; Berthold of Moosburg, Expositio, 83 B, p. 124, l. 38-43, citing Dietrich of Freiberg, Quaest. utrum in Deo, 1.1 (4), p. 294, l. 32. 


\section{$4 \quad$ Theology and Philosophy: Traces of a Lost Text?}

The Preamble to the Exposition seeks to account for the two principles that, according to Berthold, Proclus assumes as the foundations of his philosophy: Proposition 1 (Omnis multitudo etc.) assumes "that there is multitude" (multitudinem esse) and moves from the many to the One, while Proposition 7 (Omne productivum etc.) presupposes that "the productive exists" (productivum esse) and establishes the existence of the Good.

Since Proclus seems to assume these principles, Berthold was compelled, somewhat surprisingly, to address some doubts as to whether the science of the Elements of Theology is a true science at all:

These two principles, upon which all of this philosophy is built as upon its own foundations, the author assumes are grasped by the reception of the senses and are in no way intellected, known, or apprehended by another scientific habit, but are only believed, just as the theology that concerns the divine Good according to the order of voluntary providence is founded on believed principles, which are the articles of the Christian faith. For this reason, it is often doubted by many, concerning both sapiential and divinising theology, whether it is a science in the true sense of the term. ${ }^{59}$

The argument of the Preamble is then that a science founded on principles that are only believed (credita) can still be a science in the genuine sense of the word.

But who are the many (a plerisque) who denied the scientific character of Proclus' philosophy? Some, like Albert the Great and Thomas Aquinas, in an Aristotelian spirit, at times criticised the Platonists for using metaphors instead of precise terminology. But there is no precedent for any such critique directed against Proclus in the Latin world. The criticism seems to presuppose an elaborate debate about the Aristotelian character of a science, the modes of cognition by which the principles of a science are apprehended, as well as an argument that connects the reception of principles through sense-perception

59 Berthold of Moosburg, Expositio, Praeambulum A, p. 53, 1. 15-22: Ista duo principia, quibus totius istius philosophiae structura sicut propriis fundamentis innititur, auctor supponit sicut per sensus acceptionem nota et nullo modo vel intellecta vel scita vel aliquo alio habitu scientiali apprehensa, sed solum credita, sicut et theologia, quae est de bono divino secundum ordinem providentiae voluntariae, fundatur in principiis creditis, quae sunt articuli fidei Christianae. Propter quod a plerisque dubitari solet de utraque theologia et sapientiali et divinali, an sit scientia secundum veram scientiae rationem. 
with belief. In other words, some have challenged the notion that a science based on believed principles could be a science at all. This argument seems naturally suited to debates about the scientific status of revealed theology, but the application of this to the Elements is hardly a straightforward one, even within the parallel framework of the two orders of providence, and obliges us to seek out the background debate presupposed by the text.

This task is now much easier now that Berthold's extensive reliance on Thomas of York has been demonstrated. Large portions of the Preamble come directly from Thomas. ${ }^{60}$ But this is not the case for the core passages of the Preamble, namely, its verdict on the status of a science that begins from believed principles. I will suggest that these come from a lost work of Dietrich, whose title we know from the 14th-century Stams catalogue: De theologia, quod sit scientia secundum perfectam rationem scientiae. Loris Sturlese was the first to note that the final phrase of the opening passage of the Preamble, translated above, echoes the title of this lost treatise, and he intuited that a good deal of what follows in the Preamble must depend on Dietrich's lost text, but did not pursue the hypothesis any further. ${ }^{61}$ If we now look past Berthold's borrowings from Thomas to the central arguments of the Preamble, sections B and C, we begin to see many theoretical and terminological parallels with Dietrich's known works. Indeed, if we transpose these arguments into Dietrich's idiom and context, a picture emerges that is consistent with what we already know about his intellectual project. It equally reflects Berthold's adaptations and adjustments of it that were discussed in the case studies. Furthermore, this hypothesis sheds light on their decisively different approaches to the fundamental question of the relationship between philosophy and theology, and how these disciplines map on to the methodological and ontological separation of the two orders of providence. And so while the reconstruction of the argument of a lost treatise is always a delicate one, especially when one is relying on traces and tacit citations, I believe the result corroborates what

60 See Fiorella Retucci's contribution in this volume.

61 L. Sturlese, "Il De animatione caeli di Teodorico di Freiberg", in R. Creytens, P. Künzle (eds), Xenia Medii Aevi historiam illustrantia, oblata Thomae Kaeppeli O.P., vol. 1 (Roma: Edizioni di Storia e Letteratura, 1978), p. 175-247, at p. 194, n. 84: "che Bertoldo dipenda da tale quaestio, o comunque da posizioni teodoriciane, è mia netta impressione: ma non posso per ora dimostrario". See also L. Sturlese, "Introduction", Berthold de Moosburg, Commentaire des Éléments de théologie de Proclus, Préambule du livre, in R. Imbach, M.-H. Méléard (eds), Philosophes médiévaux. Anthologie de textes philosophiques (XIII ${ }_{-}$ $X I V^{e}$ siècles) (Paris: Union générale d'éditions, 1986), p. 335-346, at p. 342-343: “[...] surtout on peut envisager l'éventualité que derrière le texte du Préambule se camoufle un extrait de la Question perdue de Thierry de Freiberg Quaestio utrum theologia sit scientia secundum perfectam rationem scientiae". 
has already been established on solid ground and also opens up new paths for understanding the projects of these two Dominicans within their respective contexts.

While Dietrich was in Paris as a bachelor in theology and lecturing on the Sentences sometime between $1282-1292,{ }^{62}$ debates concerning the scientific status of theology reached "a fever pitch".63 Followers of Aquinas invoked the deductive model of Aristotle's Posterior Analytics and argued that theology is a science in the strong sense, in that our theology is subalternated to the higher science possessed by God and the blessed. To give an analogy from the human sciences, an expert geometer knows demonstratively what the practitioner of optics assumes: the geometer knows the reason why (propter quid), while the optician knows the fact that (quia). ${ }^{64}$ Among the most innovative and polarised reactions to this position were Henry of Ghent and Godfrey of Fontaines. Both went to the Posterior Analytics to criticise the subalternation theory on its own grounds. For Henry of Ghent, we must look beyond Aristotle to Christian authorities in order to ground the subalternation theory. Henry proposed his famous doctrine of the middle light (lumen medium), which the theologian possesses between the obscure light of faith, which every believer has, and the clear light of glory of God and the blessed. Godfrey of Fontaines also returned to Aristotle but opposed both Henry and the Thomists. Godfrey argued that we simply must give up calling theology a science in the strict sense. In his fourth and eighth Quodlibets from 1287 and $1292,{ }^{65}$ which probably overlapped with Dietrich's baccalaureate, ${ }^{66}$ he argued against the subalternation theory,

62 Sturlese, Dokumente und Forschungen, p. 4; Flasch, Dietrich von Freiberg, p. 3 .

63 S. Brown, "Duo Candelabra Parisiensia. Prosper of Reggio in Emilia's Portrait of the Enduring Presence of Henry of Ghent and Godfrey of Fontaines regarding the Nature of Theological Study", in J. Aertsen, K. Emery, Jr., A. Speer (eds), Nach der Verurteilung von 1277. Philosophie und Theologie an der Universität von Paris im letzten Viertel des 13. Jahrhunderts. Studien und Texte (Berlin / New York: De Gruyter, 2001), p. 320-356, at p. 323.

64 Thomas Aquinas, Summa theologiae, I.1.2. On this doctrine and its legacy, see J.-P. Torrell, "Le savoir théologique chez les premiers thomistes", in Revue thomiste 97(1997), p. 9-30, at p. $16-19,26-29$.

65 For the chronology, see J. Wippel, The Metaphysical Thought of Godfrey of Fontaines. A Study in Late Thirteenth-Century Philosophy (Washington, D.C.: The Catholic University of America Press, 1981), p. xxvii-xxviii. On Godfrey and his criticisms of Henry of Ghent, see C. König-Pralong, Le bon usage des savoirs. Scolastique, philosophie et politique culturelle (Paris: Vrin, 2011), p. 111-123.

66 Dietrich's De origine seems to use Godfrey's Quodlibet II (1286) and Henry's Quodlibet XIV (129o/1291). See L. Sturlese, Storia della filosofia tedesca nel Medioevo. Il secolo XIII (Firenze: Olschki, 1996), p. 185-188; Flasch, Dietrich von Freiberg, p. 162-165; P. Porro, "Res praedicamenti e ratio praedicamenti. Una nota su Teodorico di Freiberg e Enrico di Gand”, 
contending that any science that receives its principles from a higher science through mere belief cannot be a science in the strict sense of the term:

Therefore, to say that the principles of theology or the knowledge of anything in theology itself [are merely believed], or that in the one who is said to be knowledgeable in theology [these principles] are merely believed and are not known or intellected [sunt solum credita et non scita vel intellecta], and thus merely possess the certitude of adhesion, and nevertheless produce the certitude of knowledge in the conclusions reached from them, is to say that the conclusions would be better known than the principles, and so have a twofold certitude, while the principles would have but one [kind of certitude]. This is to say contradictory things and greatly to dishonour sacred theology and its teachers, by propagating such lies about theology to those drawn to it. ${ }^{67}$

Godfrey based his argument on a distinction between the certitude of evidence, which belongs to scientia, and the certitude of adhesion, which belongs to faith. The latter comes from adhesion to authority and is weak and imperfect compared to the certitude of scientific evidence. ${ }^{68}$ One cannot deduce stronger conclusions from weaker principles. ${ }^{69}$ Therefore, because theology relies on principles that are only believed, which are grounded only on certitude of adhesion to authority, Godfrey concluded in 1293/1294, after Dietrich had left Paris, that "theology is less properly a science than natural science".70

in J. Biard, D. Calma, R. Imbach (eds), Recherches sur Dietrich de Freiberg (Turnhout: Brepols, 2009), p. 131-143, at p. 142-143.

67 Godfrey of Fontaines, Les quatres premiers Quodlibets de Godefroid de Fontaines, eds M. de Wulf, A. Pelzer (Louvain: Institut supérieur de philosophie de l'Université, 1904), Quodlibet IV, q. 10, p. 262: Dicere ergo quod principia theologiae [...] sive apud illum qui dicitur esse sciens theologiam sunt solum credita et non scita vel intellecta et sic solum certitudinem adhaesionis habentia, et tamen efficiunt certitudinem scientiae in conclusionibus ex ipsis elicitis, est dicere quod conclusiones sint notiores principiis, scilicet duplicem certitudinem habentes, cum principia non habeant nisi unam. Et hoc est dicere contradictoria et multum derogare sacrae theologiae et doctoribus ipsius, tales fictiones de ipsa theologia attractantibus ipsam propalare.

68 Godfrey of Fontaines, Le huitième Quodlibet de Godefroid de Fontaines, ed. J. Hoffmans (Louvain: Institut supérieur de philosophie de l'Université, 1924), Quodlibet viII, q. 7, p. 73: notitia debilis vel imperfecta ad evidentiam, sed firma quantum ad adhaesionem, quia innititur auctoritati solum et non rei in se vel ostensae per rationem evidentem.

69 Godfrey of Fontaines, Quodlibet Iv, q. 10, p. 262.

70 Godfrey of Fontaines, Le neuvième Quodlibet de Godefroid de Fontaines, ed. J. Hoffmans (Louvain: Institut supérieur de philosophie de l'Université, 1928), Quodlibet IX, q. 20, p. 292: Ergo videtur quod theologia sit minus proprie scientia quam naturalis non tantum propter hoc, quia scilicet habet evidentiam quae requiritur ad scientiam, sed minorem quam 
The ensuing debate lasted well into the 14th century, with prominent responses to Godfrey coming from Duns Scotus, James of Metz, Hervaeus Natalis, and Bernard of Auvergne. What concerns us are not these details but simply the fact that after Godfrey no one held that theology is a science in the strictest demonstrative sense. Those who continued to regard it as such had to admit some flexibility into their notions of what constituted a demonstrative science. ${ }^{71}$ As we shall see, the Preamble, whether or not it relies on Dietrich's own response to his position, is no exception to this pattern.

By comparing some passages of the Preamble with Dietrich's extant works, I will argue that, if these passages are read as traces of Dietrich's lost treatise on the scientific status of theology, we can surmise that Dietrich largely accepted the way in which Godfrey had framed his own position in terms of the certitude of evidence and the certitude of adhesion. But his original manoeuvre in this context would have been to focus on the role that belief plays in every particular science that begins from without (quasi ab extrinseco), including metaphysics and theology, and in fact every science except the purely mathematical disciplines. In a sense, this argument amounts to an intensification of Godfrey's focus on subjective certitude, but in so doing redefines what constitutes a true science insofar as the stability of first principles is to be found within the cognitive process by which the subject grasps universal propositions. $^{72}$

naturalis, - immo etiam quia nec habet evidentiam quae requiritur ad illam scientiam quae debet dici proprie scientia. Propter quod dicendum esset illis, qui dicunt modo supradicto theologiam esse scientiam proprie dictam, dicentes hoc se credere, quia infinitae auctoritates sanctorum quibus in hoc credendum est videntur hoc dicere, quod non est ita. Immo nec una sola auctoritas viri magnae auctoritatis invenitur per quam possit hoc evidenter persuaderi.

71 J.-P. Torrell, Recherches thomasiennes. Études revues et augmentées (Paris: Vrin, 2000), p. 173, n. 4. For the subsequent debate, see J. Leclercq, "La théologie comme science dans la littérature quodlibétique", in Recherches de théologie ancienne et médiévale 11(1939), p. 351-374; S. Brown, "Late Thirteenth Century Theology. Scientia Pushed to its Limits", in R. Berndt, M. Lutz-Bachmann, R.M.W. Stammberger (eds), "Scientia" und "Disciplina". Wissenstheorie und Wissenschaftspraxis im 12. und 13. Jahrhundert (Berlin: Akademie Verlag, 2002), p. 79-9o; P. Porro, "Tra l'oscurità della fede e il chiarore della visione. Il dibattito sullo statuto scientifico della teologia agli inizi del XIV secolo", in L. Bianchi, C. Crisciani (eds), Forme e oggetti della conoscenza nel XIV secolo. Studi in ricordo di Maria Elena Reina (Firenze: SISMEL - Edizioni del Galluzzo, 2014), p. 195-256.

72 C. König-Pralong, "Expérience et sciences de la nature chez Dietrich de Freiberg et Berthold de Moosburg", in L. Bianchi, C. Crisciani (eds), Forme e oggetti della conoscenza nel XIV secolo, p. 107-133, compares the Praeamble with Dietrich of Freiberg's extant treatises, offers some valuable insights on the status of experimental sciences in Dietrich's extant works, and compares him with Roger Bacon. She also rightly underscores an important innovation in the scientific epistemology of the Preamble, which autonomises speculativeanalytical sciences (the purely mathematical) and the experimental-inductive sciences 
Berthold divides the Preamble into three sections: (A) on scientific principles in general; (B) on the three kinds of scientific principles, as well as the properties and character peculiar to each kind of principle; (C) on the true and properly scientific procedure of Proclus' theology. All of section A of the Preamble (70 lines) comes from Thomas of York's Sapientiale III.23 (or V.23 in the Florence manuscript), from which Berthold produces a terminological dossier of the different kinds of principles used in the sciences, such as axioms, hypotheses, and postulates. ${ }^{73}$ For the sake of brevity, I pass over the details of this inventory because they do not directly influence Berthold's response to the doubt about the scientific status of the Elements.

The aim of the Preamble is not only to respond to this doubt, but to show that Platonic philosophy in fact both meets and exceeds the Aristotelian criteria for demonstrative scientific procedure. Section B contains the crucial material that Berthold will then use to elevate Platonic above Aristotelian science in section C. I will focus first on section B which, I believe, comes from or is heavily inspired by Dietrich. ${ }^{74}$ I will then consider the ramifications of this reading by pointing to the divergent purposes to which this argument could have been put by Dietrich and by Berthold in section $C$.

Section $B$ begins with an outline of the three properties, or more specifically, the proper modes that the three kinds of principles presented in section A can assume. Berthold arranges these modes in terms of the various degrees of commonality that principles possess: some principles descend into every science, others only into some sciences, and those in the third group are proper only to one science. After these modes of commonality are explained, this

which, for the first time, are distinguished not according to their objects but according to the mode of apprehending the truth of the propositions comprising these sciences (p. 125, 128-129). However, the differences König-Pralong notes between the Preamble and Dietrich are not substantive and can be reduced to differences of emphasis: the division between analytical and experimental sciences is presented austerely in the Preamble, but this does not exclude the possibility of the mixed methods that we see in Dietrich's De iride, prol. (5). Moreover, it obscures the purpose of the Preamble to say that for Berthold Platonic science has the same certitude as mathematics (p. 129, p. 132-133). The argument of the Preamble becomes clearer when it is read as a theological text, and when its sources and interlocutors are sought in that domain.

73 See the list of citations compiled by Fiorella Retucci in this volume. For a study and edition of this section of the Sapientiale, see F. Retucci, "Nuovi percorsi del platonismo medievale. I commentari bizantini all'Etica Nicomachea nel Sapientiale di Tommaso di York", in Documenti e studi sulla tradizione filosofica medievale 24(2013), p. 85-120.

74 Only one passage in section B undoubtedly comes from Thomas of York: p. 57, l. 141-157 ( $\approx$ Sap. III.23), which explains what Aristotle means by intellectus in Nicomachean Ethics VI and Posterior Analytics using the commentary of Eustratius. 
classification is used to discuss the different modes of certitude proper to each kind of principle.

The most-common principles (communissima) descend into every science. For example, all sciences use the principle of non-contradiction..$^{75}$ The mode or condition of such principles is that they are the most secure of all and cannot deceive; they are true universally, and thus are present by nature and not by instruction. We read that these principles concern "being as being", since being (ens) is "the most universal of all formal intentions" - however, he continues, "according to Plato it is otherwise". This contrast is incomplete as it stands, and one cannot rule out that Berthold is embellishing another text. ${ }^{76}$

The second group of principles are common (communia). These are taken up "proportionately", or in their own way, only by some sciences. Examples are taken from Euclid's "common conceptions of the mind": "the whole is greater than the part" or "if equals are subtracted from equals, then the remainders are equal". ${ }^{77}$

In the third group are principles proper to particular sciences that have no proportional or analogical commonality across diverse sciences: their meaning is entirely fixed relative to the particular science in question. Examples are the principle in geometry that "all right angles are equal", in optics the principle that "light and colour move sight", or in physics that there is movement in nature.

Then we come to the various modes of certitude and truth apprehended in these three kinds of principles. The text argues that "most-common" and "common" principles are known through intellect (intellectus), and it is here that Berthold uses Thomas of York to explain how intellect differs from the other habits presented by Aristotle in Book VI of the Ethics. But the most

75 For Dietrich's use of descendere to describe the passage from the universal to the particular, see Dietrich of Freiberg, De vis. beat., 3.2.9.6 (4-6); De quid., 4.4; De int., II.14.1; De luce, $17.1-2$.

76 Berthold of Moosburg, Expositio, Praeamb. B, p. 56, l. 116-119: ens, quod est universalissima omnium intentionum formalium secundum Aristotelem, licet aliter sit secundum Platonem. Cf. Dietrich of Freiberg, De orig., 1.25, p. 144, l. 239-241: intentio enim entis prima et formalissima est omnium intentionum; 3.8, p. 159, l. 40-p. 16o, l. 48: ratio entis [...] est prima et formalissima omnium intentionum; 5.36, p. 191, l. 351-358: ens, quae est prima et formalissima omnium intentionum; Dietrich of Freiberg, De int., II.15.1, p. 156, 1. 9-10: quantum ad primam et simplicissimam et universalissimam intentionem, scilicet esse.

77 Berthold of Moosburg, Expositio, Praeamb. B, p. 56, 1. 123-126: quas communes animi conceptiones vocant et ponuntur in principio Euclidis, puta, 'si ab aequalibus aequalia demas', etc., et 'omne totum est maius sua parte'. Cf. Dietrich of Freiberg, De ir., I.4.8, p. 128, l. 58-59: per communem animi conceptionem, scilicet 'si aequalia ab aequalibus demas' etc.; I.4.10, p. 128 , l. 80-81; II.24.8, p. 186, l. 93-94. 
important point concerns the principles unique to particular sciences. Only in some sciences, the purely mathematical, are the principles apprehended by intellect. All the others, as we shall see, have a different mode of certitude and truth. The notion of a true science must have sufficient latitude to account for these, which comprise the majority, by far, of the disciplines normally regarded as sciences.

Therefore, each science must be considered separately to determine, first, whether it is purely mathematical and, second, how it relates to the physical world. Purely mathematical sciences like geometry and arithmetic have the same certitude as the most-common and common principles because their principles are known through intellect and not sense-experience. In such cases, exemplified by Euclid, the order of nature and the order of our knowledge are parallel: "we apprehend the proper principles of such sciences by intellect in the first steps in the progress in these sciences". ${ }^{78}$

Sciences relating to the physical world apprehend truth in another way and have a different degree of certitude. Such sciences include physics and ethics, where what is prior by nature is later in the order of knowing because they begin in sense-perception. Here the text cites Aristotle: "every art and intellective discipline begins from a prior sense-perception". ${ }^{79}$ The principles in these sciences are universals derived from sense, memory, and experience. For example, in physics sense-perception establishes "that there is motion", and in medicine experience establishes "that scammony purges bile". In optics and astronomy an instrument is used to capture an experimentum. In these particular sciences, there is no necessary relation between experience and the universal proposition or principle derived from it. ${ }^{80}$ Therefore, whereas intellect apprehends the principles of purely mathematical sciences as well as most-common and common principles, which have an intrinsic mode of certitude and truth, the principles of every other particular science, as we shall see, "have their cause and reason as it were from the outside" (quasi ab extrinseco).${ }^{81}$ It is relative to this domain of exteriority that the text makes the critical manoeuvre that extends the true notion of a science to those founded on believed principles. It is within this category that the text mentions "the principles of metaphysical or divine sciences". 82

78 Berthold of Moosburg, Expositio, Praeamb. B, p. 58, l. 177-178.

79 Berthold of Moosburg, Expositio, Praeamb. B, p. 59, l. 204-209.

8o Berthold of Moosburg, Expositio, Praeamb. C, p. 62, l. 331-334.

81 Berthold of Moosburg, Expositio, Praeamb. B, p. 6o, l. 241.

82 Berthold of Moosburg, Expositio, Praeamb. B, p. 6o, 1. 271-274: alia est cognitio principiorum communissimorum, communium et propriorum in scientiis pure mathematicis, quia 
Any proposition or principle derived from sense-experience in such sciences is "only believed and in no way known or intellected", since it lacks the necessity of intellect. ${ }^{83}$ These principles, as believed, are "apprehended under the certitude of the 'true', [which] cannot possibly be otherwise". This apprehension has three components: (1) the "apprehended" is what reason objectively deals with in thinking, such as "this, which is moved, exists";84 (2) it is "true" by the equality of the thing apprehended and intellect, which occurs through "a combination or composition of speech"; 85 finally, (3) "certitude" is "the firm and unshakeable assent of reason" concerning the thing apprehended as true.

Within this framework, the text compares mathematical and physical sciences. What is known demonstratively (scitum) by intellect is also "apprehended by reason under the certitude of truth", but the principle that is believed (creditum) differs from it in two respects: (1) by its mode of certitude and (2) in the order of apprehension. (1) Scientia takes its certitude from the intrinsic evidence of the thing, that is, from the intention and rational relations which the terms have to one another in a complex proposition, whether immediately in the case of first principles, or mediately, when a conclusion is deduced from prior principles. By contrast, the certitude of faith derives not from intrinsic evidence, but has its cause and reason from without (quasi ab

intellectus, alia vero metaphysicorum seu divinorum, physicorum et ad physica relatorum, quia acceptio secundum sensum.

83 Berthold of Moosburg, Expositio, Praeamb. B, p. 59, 1. 217-229: Sic igitur procedente indagatione per viam sensus et experientiae in praemissis scientiis sumptum est unum universale pro ipsarum scientiarum principio, quod principium in quacumque huiusmodi scientia solum creditum est et nullo modo scitum nec intellectum, quia nec ex propria ratione terminorum cognitum est, quod esset intelligere, nec ex aliquibus principiis aliis seu causis conclusum et ita nullo modo scitum, sed, ut dictum est, solum est creditum, et sic apprehensum sub certitudine veri, quod impossibile est aliter se habere. Dico autem [1] 'apprehensum' id, circa quod obiective negotiatur ratio per cognitionem, ut hoc, quod est motum, esse; [2] 'verum' autem hic intelligo ipsam aequalitatem sive consonantiam rei apprehensae et intellectus, quae quantum ad rationem et modum attenditur circa complexionem sive compositionem locutionis; [3] 'certitudo' autem de ipsa veritate rei apprehensae est firmus et indeclinabilis assensus rationis in rem sic apprehensam.

84 Berthold of Moosburg, Expositio, Praeamb. B, p. 6o, 1. 249-25o clarifies that these are first intentions. Cf. Dietrich of Freiberg, De orig., 5.47, p. 194, 1. 463-468: Circa quaedam enim entia sic negotiatur intellectus [...]; 5.54, p. 197, 1. 566-568: Unde huiusmodi entia proprie dicuntur res rationis, non autem ea, quae sunt primae intentionis, quae important aliquam rem naturae et circa quae negotiatur intellectus tamquam circa res naturae.

85 Presumably this occurs through affirmation and negation, and second intentions. This rare expression, complexio locutionis, appears also in Dietrich of Freiberg, De orig., 5.54, p. 197, l. 559-562: Possunt enim non entia, sicut et entia, in complexionem locutionis et in praedicationem affirmativam vel negativam venire [...]; Dietrich of Freiberg, De nat. contr., 13.1, p. 93, l. 44-55. 
extrinseco), such as "from the clear authority of an expert, from whose truth the intellect cannot reasonably dissent". ${ }^{86}$ At this stage, one should note that scientia and fides align closely with what Godfrey called the certitude of evidence, where knowledge begins with per se principles that lead to clear conclusions, and the certitude of adhesion, which begins from authority.

(2) The second difference between scientia and fides concerns the order of apprehension. In scientia, the evidence of the thing arises from the intention and rational relation of the terms which are, so to speak, "the intrinsic principle of cognition found in the thing" ${ }^{87}$ The thing itself is by nature apprehended first, prior to truth or falsehood, which both arise from the combining activity of intellect. By contrast, in belief, the authority of an expert comes first, "in whose truth reason declares our trust must absolutely be placed and the will inclines to it". 88 In belief, the order of apprehension begins with truth as such and not with the intrinsic evidence of the thing. Any necessity lacking in the evidence of the terms is supplied by the authority of an expert, which provides the secure foundation of truth.

What remains to be determined is whether there can be a true science (vera scientia) which begins from belief. Section C of the Preamble is based on establishing an analogy between theology and natural science. Godfrey did not accept this analogy. But the argument in the Preamble will make room for it insofar as it has found a role for belief in the physical sciences. In a moment we shall pause to consider the implications of the possibility that, if Berthold is indeed using Dietrich's De theologia, substantial modifications follow from his repurposing of its argument: he would have placed Platonic philosophy where Dietrich would have put revealed theology, for section C argues that Platonic wisdom (divinalis sapientia) has the same scientific structure, proportionately speaking (proportionaliter loquendo), as the other genuine sciences,

86 Berthold of Moosburg, Expositio, Praeamb. B, p. 6o, 1. 241-242: puta ex evidenti auctoritate alicuius experti, a cuius veritate intellectus rationabiliter dissentire non potest.

87 Berthold of Moosburg, Expositio, Praeamb. B, p. 6o, 1. 248-250: quae sunt quasi intrinsecum cognitionis principium repertum apud rem ipsam, prout est ens et res primae intentionis. Cf. Dietrich of Freiberg, De acc., 8.4, p. 64, 1. 110-113: universitas entium, quae sunt res primae intentionis et vere res naturae, in duplicem maneriem rerum distinguitur secundum duas differentias entis in eo, quod ens, quae est prima et simplicissima omnium formalium intentionum repertarum in rebus; Dietrich of Freiberg, De vis. beat., 3.2.9.1 (3), p. 86, 1. 26-33.

88 Berthold of Moosburg, Expositio, Praeamb. B, p. 6o, l. 254-56: Quia enim causam et rationem suae certitudinis non habet a re ipsa, sed ab auctoritate alicuius experti, cuius veritati omnino standum esse dicit ratio et inclinat voluntas [...]. 
except the purely mathematical. ${ }^{89}$ That is, it uses most-common principles (e.g., non-contradiction) and common principles (e.g., "the whole is greater than the part"), which are apprehended by intellect. As for the two principles unique to this science, "there is multitude" and "there is producer and produced", Berthold states that Proclus assumes them and "proceeds perfectly following the scientific mode". In this most divine science (divinissima scientia), these two principles are known in a way analogous (proportionaliter) to the sciences concerning things conjoined to motion or change. While Berthold does not explicitly say so, this requires that we understand both the elements of similarity and difference in the analogy.

In terms of similarity, this theology resembles those sciences in which there is no necessary connection between sense-experience and the universal proposition: their principles must be believed. The text explains this with an important account of the cognitive structure of belief which, however, is subtly different from the grounding of authority in section $\mathrm{B}$ :

Therefore, in taking this universal principle from sense-experiences there is nothing but a conjectural inference under the aspect of the true and not under the aspect of being, as has been said. Accordingly, it is received as believed, not as intellected or known [ut creditum, non ut intellectum vel scitum]. As has been said, it is taken by a certain conjecture, but still with the firm and unwavering assent of reason. This firmness and unwavering assent arises from a certain natural instinct founded in the power that at once distinguishes, collects, and gathers, which we call the cogitative. In and through this power the simple and pure intentions of things, separated from their images, to use the phrase of Averroes, are apprehended, distinguished, collected, and gathered. ${ }^{90}$

89 Berthold of Moosburg, Expositio, Praeamb. C, p. 61, l. 307-309: omnino eodem modo proportionaliter loquendo secundum proprium modum scientiae procedit haec divinalis sapientia sicut praedictae scientiae solis pure mathematicis exclusis.

90 Berthold of Moosburg, Expositio, Praeamb. C, p. 62, l. 340-349: Igitur in sumptione talis universalis principii ex sensibilibus experimentis non est nisi quaedam coniecturalis illatio sub ratione veri et non sub ratione talis entis secundum praemissa, et ideo solum accipitur ut creditum, non ut intellectum vel scitum, et, ut dictum est, sumitur secundum quandam coniecturam, cum firmo tamen et indeclinabili assensu rationis. Quae firmitas et indeclinabilis assensus surgit ex naturali quodam instinctu fundato in virtute distinctiva et collectiva simul et collativa, quam cogitativam dicimus, in qua seu per quam apprehenduntur, distinguuntur, colliguntur, conferuntur simplices et purae rerum intentiones separatae a suis idolis, ut verbo Averrois utar. 
The universal principle is thus a conjectural inference that is believed with the assent of reason, all of which occurs in the cogitative power; the "true" as such, rather than the thing itself, is still primary. However, its solidity comes not from authority but from the cogitative power itself, which separates the intentions stored in memory and acquired by sense-perception. Its activity is rational and automatic. There are passages from Dietrich of Freiberg that closely resemble this description of the cogitative power and its close association with the estimative faculty, ${ }^{91}$ its phrasing, ${ }^{92}$ and its terminology of conjecture. ${ }^{93} \mathrm{An}$ argument like this would serve as a strong reply to Godfrey of Fontaines, in that it has effectively extended the certitude of adhesion beyond the domain of revealed theology to all physical sciences; there is an act of belief in all such scientific habits.

The fundamental assumption here requires that we accept the analogy between what we might call, importing Godfrey's language, the certitude of adhesion to authority and the certitude of adhesion to a conjectural inference. The text emphasizes how, in the order of apprehension, both in some sense come from without (quasi ab extrinseco), and both are grasped primarily as true with enough firmness to serve as a basis for scientific knowledge. Nevertheless, we should recall that there must also be an element of difference in the analogy between theology and natural philosophy or, in other words, between authority and inference: one, for example, proceeds automatically (the conjecture) and one is voluntary (assenting to authority). This difference in the analogy is, however, not resolved or even acknowledged in the Preamble.

91 Dietrich of Freiberg, De int., III.27.2, p. 200, 1. 26-32: Ratio particularis, quam etiam aestimativam seu cogitativam vocant, est vis distinctiva, quae componit et dividit et versatur circa intentiones rerum, etiamsi sint res universales, universales, inquam, secundum considerationem, inquantum videlicet considerat rem aliquam absque principiis secundum considerationem individuantibus seu particulantibus eam. Et hoc est, quod ille commentator Averroes dicit, scilicet quod denudate rem a suo idolo, id est ab accidentibus, sub quibus imaginativa rem considerat. See also Dietrich of Freiberg, De orig., 5.26, p. 187, l. 224-p. 188, l. 228; Dietrich of Freiberg, De int., III.7.5, p. 182, l. 112-p. 183, l. 120; III.17.1, p. 19o, l. 3-9; III.33.1-2, p. 204, l. 28-53; Dietrich of Freiberg, Quaestio utrum in Deo, 1.4.2.2 (11), p. 302, 1. 78-88; Dietrich of Freiberg, De vis. beat., 3.2.9.7 (4), p. 98, 1. 21-33; 4.3.2 (9), p. 115, l. 40-54; Dietrich of Freiberg, De sub. spir., 4.6, p. 306, l. 96-101.

92 Dietrich of Freiberg, De vis. beat., Prooemium (4), p. 14, 1. 40 and 1.2.2.1 (8), p. 47, 1. 51: ut verbo eius [Augustini] utar; 3.2.4 (10), p. 75, l. 48: ut verbis eius [Aristotelis] utar; Dietrich of Freiberg, De int., III.2.1, p. 179, l. 21; Dietrich of Freiberg, De magis, 11.4, p. 55, l. 68; Dietrich of Freiberg, De anim., 10.4, p. 22, l. 96-97 and Dietrich of Freiberg, De ir., IV.23.5, p. 265, l. 112: ut verbis Philosophi utar; Dietrich of Freiberg, De intellig., 5.10, p. 36o, l. 94-95: ut verbis philosophorum utar; Dietrich of Freiberg, De anim., 9.1, p. 20, 1. 48-49: ut philosophorum verbis utar.

93 Dietrich of Freiberg, De int., II.37.1, p. 175, l. 2: coniciendum; Dietrich of Freiberg, De nat. contr., 56.2, p. 123, l. 35 : conicimus. See also note 98 , below. 
But if we entertain the hypothesis about the De theologia and the origin of this argument in Dietrich, we find in his works the resources to resolve this tension. Of the greatest importance here is the De subiecto theologiae, which is transmitted in Berthold's own hand (MS Basel, Universitätsbibliothek, F.IV.31, f. 69v). ${ }^{94}$ In this fragment, we find a similar approach to that of the Preamble: Dietrich reasons about the subject of theology by analogy with natural philosophy, relying mainly on Aristotle and Averroes. ${ }^{95}$ This fragment also, of course, contains the programmatic distinction of natural and voluntary providence used by Berthold in the Exposition of the Title that precedes the Preamble. It is this distinction that could address the tension between authority and conjecture, insofar as the natural, automatic assent of the cogitative power would pertain to what the fragment calls "the divine science of the philosophers", while the free assent to the authority of Scripture would relate to what Dietrich variously calls our science (nostra scientia), theology as such (theologia simpliciter), and our divine science of the saints (nostra divina sanctorum scientia). ${ }^{96}$ Dietrich frames the difference between the two theologies eschatologically: the divine science of the saints looks beyond the limits of this world and will outlast those limits, when the mundane wisdom of the philosophers will be destroyed. The arguments about authority and conjectural inference in the Preamble could be used toward a similar end. That is, while metaphysics or the divine science of the philosophers begins from believed principles, and

94 See Loris Sturlese's introduction to the critical edition of the text in Dietrich von Freiberg, Opera omnia, vol. 3. Schriften zur Naturphilosophie und Metaphysik, p. 277.

95 Dietrich of Freiberg, De subiecto, 2.2, p. 279, l. 10-2o and 3.2-3, p. 28o, 1. 35-58. Presumably the De subiecto would have followed the De theologia; we ask about the subject of theology after determining whether it is a science.

96 Dietrich of Freiberg, De subiecto, 3.8-10, p. 281, 1. 92-p. 282, 1. 112: Quamvis autem quantum ad considerationem primi philosophi talis etiam, quae dicta est, attributio entium ad primum principium attendatur, et propter hoc etiam potius dicitur apud philosophos scientia divina seu theologia, quam dicatur metaphysica - considerat enim primo et principaliter de ente divino, quod est divinum per essentiam, consequenter autem de aliis, unde in XII talia ostendit ordinari in ipsum tamquam in universitatis principem - nihilominus tamen nostra scientia, quam vere et simpliciter theologiam dicimus, distinguitur a scientia divina philosophorum. Scientia enim divina philosophorum considerat universitatem entium secundum ordinem providentiae naturalis, quo videlicet res stant in sui natura et secundum suos modos et proprietates naturales gubernantur per principem universitatis, nec ultra hunc naturae ordinem aliquem ulteriorem finem attendit. Nostra autem divina sanctorum scientia attenditur in entibus, secundum quod stant et disponuntur sub ordine voluntariae providentiae, in quo attenditur ratio meriti et praemii et ea, quae attenduntur circa bonam et sanctam vitam et adeptionem aeternae beatitudinis et perventionem ad finem ulteriorem sive in bono sive in malo etiam post terminum huius mundi, quando scientia divina sapientium huius mundi destruetur, I Cor., 13. Secundum praedicta igitur convenienter accipitur subiectum huius nostrae scientiae divinae, videlicet ut dicatur ens divinum secundum ordinem voluntariae providentiae. 
nevertheless is a legitimate science, the free assent to the infinite authority of Scripture surpasses it in its certitude. For metaphysics begins with principles deriving from sense, memory, and experience, and as Dietrich writes elsewhere, even though the cogitative power gives spontaneous, firm assent, it is not infallible. ${ }^{97}$

Assumptions like these help us understand why Dietrich habitually qualified his assent to the positions of the philosophers regarding the existence of separate intelligences. As was noted above, he uses caveats like these at least 40 times. And yet, at the same time, Dietrich maintains that the philosophers' arguments are the most rationally compelling option and upholds them against those who haphazardly mingle revealed and natural principles. He sums it up in a phrase: "we rationally conjecture" (rationabiliter conicimus) about such things as the order of the universe, the movers of the heavens, the separate intelligences, the nature of spiritual places and their inhabitants, and the character of the beatific vision. ${ }^{98}$ Our theoretical knowledge of these realities remains tentative; only in ethics and the order of voluntary providence do we reach the things themselves.

But we must return to Berthold, whose Preamble importantly does not resolve the tensions between conjecture and authority, between natural and voluntary providence, between the divine science of Proclus and Christian theology. Berthold leaves all of these questions open. Where Dietrich underscores the disproportion between revealed theology and the divine science of the philosophers, Berthold instead spends the remainder of the Preamble underscoring the supremacy of Platonic supersapientia over Aristotelian sapientia. From this point until the end of the Preamble we are on surer footing

97 Dietrich of Freiberg, De hab., 9.1-2, p. 14, 1. 62-72: veniemus ad aliquid magis intimum, et hoc eo intimius, ut ita loquamur, quo spiritualius, et est phantasticum nostrum exspoliatum idolis et corporalibus rerum similitudinibus retinens apud se rei intentionem. Et istud vocamus cogitativum nostrum. Et hic oritur aestimativa et per consequens ratio particularis. Et operatio boni vel mali hinc surgit; consequenter autem ratio et proprietas virtutis operativae. Sine hac vi spirituali daemon numquam fuisset lapsus. Ruina enim sua fuit eo, quod inclinavit se in aestimatum bonum, quod non fuit verum. Intellectus autem semper verorum est.

98 Dietrich of Freiberg, De anim., 5.3, p. 16, l. 20: rationabiliter conicimus; 20.1, p. 30, l. 78 : rationi, qua conicimus; Dietrich of Freiberg, De cog. ent., 44.9, p. 210, l. 101: rationabiliter conicitur; 81.4, p. 243, l. 97: rationabiliter conicitur; Dietrich of Freiberg, De dot., 13.3, p. 279, 1. 30: rationabiliter conicitur; Dietrich of Freiberg, De magis, 14.3, p. 58, 1. 75: rationabiliter conicitur; Dietrich of Freiberg, De sub. spir., 11.1, p. 311, 1. 76-77: possumus et de eis conicere tamquam a simili ex tertia manerie entium conceptionalium; 14.1, p. 313, 1. 13-14: aliqualiter conicere possumus de locis dictorum entium realium; Dietrich of Freiberg, De vis. beat., 4.1 (6), p. 106, l. 33-34: tamen circa hoc probabiliter ex ratione conicere. 
about his sources: Berthold uses his characteristic synthesis of Dionysius and Proclus concerning what is beyond intellect, and returns to Thomas of York for materials relating to Aristotle. This coincides with a shift in terminology. In the passage reminiscent of Dietrich, translated above, it was "we" who call the cogitative the virtus distinctiva et collectiva simul et collativa. Now, as Berthold turns to Proclus, it is "they" who call the ratio particularis the cogitativa (rationem particularem, quam quidam cogitativam vocant). ${ }^{99}$ But much more tellingly, whereas Dietrich in the De subiecto theologiae was careful to distinguish between "our theology of the saints" and "the divine science of the philosophers", with Berthold the mark of ownership passes to the speculative habit of the Platonists: habitus nostrae divinalis supersapientiae and nostra supersapientialis et divinalis sapientia. ${ }^{100}$ Berthold can make this transposition because of what he understands the fundamental achievement of Platonism to be and what the consequences are of realizing that the best of the pagans had achieved a divine cognition beyond intellect. Proclus in the Elements of Theology followed the oblique motion of the soul, ascending to God by reasoning, and he must have begun with the certainty of conjectural inference. Eventually, through intellectual practice and virtue, silencing all motions external and internal, he was elevated to the direct and ecstatic knowledge through ignorance that is the unum animae or divine madness. For Berthold, what Dionysius says about the cognition beyond the mind describes the habit of Platonic theology:

According to this [unity], therefore, it is necessary to think divine things, not according to ourselves, but ourselves wholly placed wholly outside ourselves and wholly deified. For it is better to be God's and not our own. ${ }^{101}$

For Thomas Aquinas, in his commentary on the same text, Dionysius is referring to the gift of faith. ${ }^{102}$ But the undeniable parallels between Dionysius and

99 Berthold of Moosburg, Expositio, Praeamb. C, p. 63, l. 378-379.

100 Berthold of Moosburg, Expositio, Praeamb. C, p. 65, l. 454-p. 66, l. 455 and p. 67, l. 514.

101 Berthold of Moosburg, Expositio, Praeamb. C, p. 64, l. 410-415: Secundum hanc igitur divina oportet intelligere, non secundum nos, sed totos nos ipsos extra totos nos ipsos statutos et totos deifactos. Melius est enim esse Dei et non nostri ipsorum. Cf. Dionysius, De divinis nominibus 7.1, 865C-868A.

102 Thomas Aquinas, In librum beati Dionysii De divinis nominibus Expositio, ed. C. Pera (Torino: Marietti, 1950), lib. viI, lect. 1, n. 705, p. 262: secundo vero, habet quamdam unitionem ad res divinas per gratiam, quae excedit naturam mentis nostrae, per quam unitionem, coniunguntur homines per fidem aut quamcumque cognitionem, ad ea quae sunt super naturalem mentis virtutem. Cf. Thomas Aquinas, Super Boetium De Trinitate, ed. P.-M.J. Gils (Roma / Paris: Commissio Leonina / Cerf, 1992), q. 2, a. 2, p. 95, 1. 65-77: Et 
the Tria opuscula have changed the parameters. Berthold would be well-aware of the similar formulations in Dionysius, where faith is described as the locating of the soul in the highest truth, ${ }^{103}$ and in Proclus, for whom the unum animae locates the soul in the divine, whence it lives by the divine life. ${ }^{104}$ If he has indeed made use of Dietrich's De theologia in the Preamble, then we see that the only words Berthold could find to express the supremacy of Platonism over Aristotelian metaphysics were those that his most esteemed modern master had used to elevate Christian theology over the divine science of the philosophers.

In the first words of the commentary, we read that St. Paul was aware of the hidden things of God because he was taken up into the third heaven in rapture. Berthold's emphasis on this putative detail from his biography suggests that, from the commentator's point of view, this rapturous knowledge was the basis for Paul's recognition that the philosophers, by reasoning from the creatures of the world, knew the invisible things of God, including the Trinity, and the ideas, primordial causes, or gods in the divine Word. ${ }^{105}$ As Augustine says, the vision of these ideas makes the soul blessed. ${ }^{106}$ Paul's transitory rapture therefore has the same content as the revelation granted to Proclus, Plato, and the pre-Platonic theologians. So, we are left to ask, what is the difference between the habit of faith and the habit of supersapientia? The end appears to be the same: to live by the divine life and to be moved by the providential Good in the silence beyond the mind. The best of the pagan Platonists saw the homeland and they reached it. Whatever differences remain, then, must concern the means to that end. Perhaps faith and the sacraments are a more immediate

secundum hoc de divinis duplex scientia habetur: una secundum modum nostrum, qui sensibilium principia accipit ad notificandum divina, et sic de divinis philosophi scientiam tradiderunt, philosophiam primam scientiam divinam dicentes; alia secundum modum ipsorum divinorum, ut ipsa divina secundum se ipsa capiantur, quae quidem perfecte in statu viae nobis est impossibilis, sed fit nobis in statu viae quaedam illius cognitionis participatio et assimilatio ad cognitionem divinam, in quantum per fidem nobis infusam inheremus ipsi primae veritati propter se ipsam.

103 Dionysius, De divinis nominibus 7.4, 872C (Dionysiaca, vol. 1, p. 409-410): divina fides est, quae est manens credentium collocatio, quae istos collocat in veritate.

104 Berthold of Moosburg, Expositio, Prol. 16, p. 25, 1. 650-652: per unum, quod est intellectu divinius, 'in quod consummans anima et locans se ad ipsam divina est et vivit divina vita, secundum quod huic est licitum'. Cf. Proclus, De decem dubitationibus circa providentiam, 10.64 , p. 106, 1. 11-12.

105 Berthold of Moosburg, Expositio, Prol. 1, p. 31, 1. 5-8: Summus divinalis sapientiae theologus Paulus secretorum Dei conscius utpote in tertium caelum raptus loquens de mundanae philosophiae sapientibus, postquam dixerat: 'Quod notum est Dei, manifestum est illis: Deus enim illis revelavit' [Rom. 1:19], subiungit: 'Invisibilia Dei' [Rom. 1:20] etc.

106 Berthold of Moosburg, Expositio, Prol. 20, p. 33, l. 935: [...] quarum visione fit beatissima. 
and broadly accessible perfection of the mind and soul than that attained through the intellectual labours of philosophical science. Berthold, however, was more interested in recalling his contemporaries to the ultimate origin and goal that was in danger of being forgotten than underlining any differences in the means.

Reading the Exposition with an eye to its tacit sources, it seems that, for Berthold, Dietrich of Freiberg was the exemplary contemporary master or sage. Berthold's first gesture towards Dietrich in the commentary is to turn the master's criticism of imaginative metaphysics against himself. In so doing, he separates the Aristotelians, who reason "according to ourselves", from the Platonists, who reason according to what is beyond ourselves. This critique provides the philosophical foundation for the dogmatic authority of Proclus and Dionysius. In relation to this authority, Dietrich's metaphysics must either be simplified (case 2) or elaborated (case 3). Moreover, since the measure of truth was historically actual in the consensus of the greatest sages of antiquity, Berthold could not accommodate Dietrich's hypothetical attitude toward the cosmology of the divine science of the philosophers. The critical sapiens modernus gave way to authoritative ancient wisdom. In Part 4, I suggested that this corresponded to a profoundly different understanding of philosophy and revelation in our two authors, which emerged once we situated the core argument of the Preamble in the context of late 13th-century Paris.

If we accept this hypothesis, then it becomes clear that all three prefaces to Berthold's commentary follow the same intertextual pattern: to express the ancient accord of Dionysius and Proclus that confronts him, Berthold took arguments that his contemporaries used to describe the nobility of revealed theology. For Dietrich, the difference of natural and voluntary providence corresponded to that of pagan and Christian theologies; the divide between theoretical and practical reason would only be overcome in the end times, and until then the natural arguments of the philosophers, used self-critically, are usually the best tool we have to understand the order of reality. For Berthold, the paths of natural and voluntary providence, theoretical and practical reason, knowledge and action, are only methodologically separate; in the discipline of Platonic science, the realisation of the unum animae, and active union with the divine providence, they must be one. Thus, for Berthold of Moosburg, the difference of pagan and Christian philosophical theology is overcome in "the philosophical revelation" of Platonism as such. 


\section{Bibliography}

\section{Manuscripts}

Basel, Universitätsbibliothek, F.IV.31.

\section{Primary Sources}

Berthold of Moosburg, Expositio super Elementationem theologicam Procli. Propositiones 1-13, eds M.R. Pagnoni-Sturlese, L. Sturlese, Hamburg, Meiner, 1984.

Berthold of Moosburg, Expositio super Elementationem theologicam Procli. Propositiones 14-34, eds L. Sturlese, M.R. Pagnoni-Sturlese, B. Mojsisch, Hamburg, Meiner, 1986.

Berthold of Moosburg, Expositio super Elementationem theologicam Procli. Propositiones 35-65, ed. A. Sannino, Hamburg, Meiner, 2001.

Berthold of Moosburg, Expositio super Elementationem theologicam Procli. Propositiones 66-107, ed. I. Zavattero, Hamburg, Meiner, 2003.

Berthold of Moosburg, Expositio super Elementationem theologicam Procli. Propositiones 108-135, ed. F. Retucci, Hamburg, Meiner, 2011.

Berthold of Moosburg, Expositio super Elementationem theologicam Procli. Propositiones 136-159, ed. F. Retucci, Hamburg, Meiner, 2007.

Berthold of Moosburg, Expositio super Elementationem theologicam Procli. Propositiones 16o-183, eds U.R. Jeck, I.J. Tautz, Hamburg, Meiner, 2003.

Berthold of Moosburg, Expositio super Elementationem theologicam Procli. Propositiones 184-211, ed. L. Sturlese, Hamburg, Meiner, 2014.

Dietrich of Freiberg, Opera omnia, vol. ı. Schriften zur Intellekttheorie, ed. B. Mojsisch, Hamburg, Meiner, 1977.

Dietrich of Freiberg, Opera omnia, vol. 2. Schriften zur Metaphysik und Theologie, eds R. Imbach et al., Hamburg, Meiner, 1980.

Dietrich of Freiberg, Opera omnia, vol. 3. Schriften zur Naturphilosophie und Metaphysik, eds J.-D. Cavigioli et al., Hamburg, Meiner, 1983.

Dietrich of Freiberg, Opera omnia, vol. 4. Schriften zur Naturwissenschaft, Briefe, eds M.R. Pagnoni-Sturlese et al., Hamburg, Meiner, 1985.

Dionysius the ps.-Areopagite, Dionysiaca, recueil donnant l'ensemble des traductions latines des ouvrages attribués au Denys de l'Aréopage, ed. Ph. Chevallier, Bruges, Desclée de Brouwer, 1937.

Godfrey of Fontaines, Les quatres premiers Quodlibets de Godefroid de Fontaines, eds M. de Wulf, A. Pelzer, Louvain, Institut supérieur de philosophie de l’Université, 1904.

Godfrey of Fontaines, Le huitième Quodlibet de Godefroid de Fontaines, ed. J. Hoffmans, Louvain, Institut supérieur de philosophie de l'Université, 1924.

Godfrey of Fontaines, Le neuvième Quodlibet de Godefroid de Fontaines, ed.J. Hoffmans, Louvain, Institut supérieur de philosophie de l'Université, 1928. 
Macrobius, Commentarii in Somnium Scipionis, ed. J. Willis, Leipzig, Teubner, 1970.

Proclus, Tria opuscula. De providentia, libertate, malo, interprete Guillelmo de Moerbecca, ed. H. Boese, Berlin, De Gruyter, 196o.

Siger of Brabant, Quaestiones in Metaphysicam, ed. A. Maurer, Louvain-la-Neuve, Éditions de l'Institut supérieur de philosophie, 1983.

Thomas Aquinas, In librum beati Dionysii De divinis nominibus Expositio, ed. C. Pera, Turin, Marietti, 1950.

Thomas Aquinas, Super Boetium De Trinitate; Expositio libri Boetii De ebdomadibus, eds L.-J. Bataillon, C.A. Grassi, P.-M.J. Gils, Rome / Paris, Commissio Leonina / Cerf, 1992.

\section{Secondary Sources}

Aertsen, J., Medieval Philosophy as Transcendental Thought. From Philip the Chancellor (ca. 1225) to Francisco Suárez, Leiden, Brill, 2012.

Brown, S., "Duo Candelabra Parisiensia. Prosper of Reggio in Emilia's Portrait of the Enduring Presence of Henry of Ghent and Godfrey of Fontaines regarding the Nature of Theological Study", in J. Aertsen, K. Emery, Jr., A. Speer (eds), Nach der Verurteilung von 1277. Philosophie und Theologie an der Universität von Paris im letzten Viertel des 13. Jahrhunderts. Studien und Texte, Berlin / New York, De Gruyter, 2001, p. 320-356.

Brown, S., "Late Thirteenth Century Theology: Scientia Pushed to its Limits", in R. Berndt, M. Lutz-Bachmann, R.M.W. Stammberger (eds), "Scientia" und "Disciplina". Wissenstheorie und Wissenschaftspraxis im 12. und 13. Jahrhundert, Berlin, Akademie Verlag, 2002, p. 79-9o.

Calma, D., Le Poids de la citation. Étude sur les sources arabes et grecques dans l'œuvre de Dietrich de Freiberg, Fribourg, Academic Press, 2010.

Calma, D., "Maneries", in I. Atucha et al. (eds), Mots médiévaux offerts à Ruedi Imbach, Porto, Fédération Internationale des Instituts d'Études Médiévales, 2011, p. 433-444.

Flasch, K., Dietrich von Freiberg. Philosophie, Theologie, Naturforschung um 1300, Frankfurt am Main, Klostermann, 2007.

Führer, M., Gersh, S., "Dietrich of Freiberg and Berthold of Moosburg”, in S. Gersh (ed.), Interpreting Proclus. From Antiquity to the Renaissance, Cambridge, Cambridge University Press, 2014, p. 299-317.

Grabmann, M., "Studien über Ulrich von Straßburg", in Zeitschrift für katholische Theologie 29(1905), p. 607-63o.

Hellmeier, P., "Der Intellekt ist nicht genug. Das proklische unum in nobis bei Berthold von Moosburg”, in Philosophisches Jahrbuch 126/2(2019), p. 202-226.

Iremadze, T., Konzeptionen des Denkens im Neuplatonismus. Zur Rezeption der Proklischen Philosophie im deutschen und georgischen Mittelalter. Dietrich von Freiberg - Berthold von Moosburg - Joane Petrizi, Amsterdam, Grüner, 2004.

King, E., "Berthold of Moosburg on Intellect and the One of the Soul", in Dionysius 36(2018), p. 184-199. 
King, E., "Eriugenism in Berthold of Moosburg's Expositio super Elementationem theologicam Procli", in D. Calma (ed.), Reading Proclus and the Book of Causes, Volume 1. Western Scholarly Networks and Debates, Leiden, Brill, 2019, p. 394-437.

König-Pralong, C., Le bon usage des savoirs. Scolastique, philosophie et politique culturelle, Paris, Vrin, 2011.

König-Pralong, C., "Expérience et sciences de la nature chez Dietrich de Freiberg et Berthold de Moosburg”, in L. Bianchi, C. Crisciani (eds), Forme e oggetti della conoscenza nel XIV secolo. Studi in ricordo di Maria Elena Reina, Firenze, SISMEL Edizioni del Galluzzo, 2014, p. 107-133.

Krebs, E., Meister Dietrich (Theodoricus Teutonicus de Vriberg). Sein Leben, seine Werke, seine Wissenschaft, Münster, Aschendorff, 1906.

Leclercq, J., "La théologie comme science dans la littérature quodlibétique", in Recherches de théologie ancienne et médiévale 11(1939), p. 351-374.

Libera, A. de, La mystique rhénane. D’Albert le Grand à Maître Eckhart, Paris, Seuil, 1994.

Ludueña, E., La recepción de Eriúgena en Bertoldo de Moosburg. Un aporte sobre la Escuela de Colonia, Saarbrücken, Publicia, 2013.

Mojsisch, B., "Die Theorie des Intellekts bei Berthold von Moosburg. Zur Proklosrezeption im Mittelalter", in Th. Kobusch, B. Mojsisch, O. Summerell (eds), Selbst Singularität - Subjektivität: Vom Neuplatonismus zum Deutschen Idealismus, Amsterdam, Grüner, 2002, p. 175-184.

Porro, P., "Res praedicamenti e ratio praedicamenti. Una nota su Teodorico di Freiberg e Enrico di Gand", in J. Biard, D. Calma, R. Imbach (eds), Recherches sur Dietrich de Freiberg, Turnhout, Brepols, 2009, p. 131-143.

Porro, P., "Tra l'oscurità della fede e il chiarore della visione. Il dibattito sullo statuto scientifico della teologia agli inizi del XIV secolo", in L. Bianchi, C. Crisciani (eds), Forme e oggetti della conoscenza nel XIV secolo. Studi in ricordo di Maria Elena Reina, Firenze, SISMEL - Edizioni del Galluzzo, 2014, p. 195-256.

Retucci, F., "Tommaso di York, Eustrazio e la dottrina delle idee di Platone", in A. Beccarisi, R. Imbach, P. Porro (eds), Per perscrutationem philosophicam. Neue Perspektiven der mittelalterlichen Forschung. Loris Sturlese zum 6o. Geburtstag gewidmet, Hamburg, Meiner, 2008, p. 79-111.

Retucci, F., "Nuovi percorsi del platonismo medievale. I commentari bizantini all'Etica Nicomachea nel Sapientiale di Tommaso di York", in Documenti e studi sulla tradizione filosofica medievale 24(2013), p. 85-120.

Steel, C., "The Neoplatonic Doctrine of Time and Eternity and its Influence on medieval Philosophy", in P. Porro (ed.), The Medieval Concept of Time. Studies on the Scholastic Debate and its Reception in Early Modern Philosophy, Leiden, Brill, 2001, p. $3^{-32 .}$ 
Sturlese, L., "Il De animatione caeli di Teodorico di Freiberg", in R. Creytens, P. Künzle (eds), Xenia Medii Aevi historiam illustrantia, oblata Thomae Kaeppeli O.P., vol. 1, Roma, Edizioni di Storia e Letteratura, 1978, p. 175-247.

Sturlese, L., Dokumente und Forschungen zu Leben und Werk Dietrichs von Freiberg, Hamburg, Meiner, 1984.

Sturlese, L., "Introduction", in Berthold de Moosburg, Commentaire des Éléments de théologie de Proclus, Préambule du livre, eds R. Imbach, M.-H. Méléard, Philosophes médiévaux. Anthologie de textes philosophiques (XIII ${ }^{e-X I V^{e}}$ siècles), Paris, Union générale d'éditions, 1986, p. 335-346.

Sturlese, L., Storia della filosofia tedesca nel Medioevo. Il secolo XIII, Firenze, Olschki, 1996.

Sturlese, L., Homo divinus. Philosophische Projekte in Deutschland zwischen Meister Eckhart und Heinrich Seuse, Stuttgart, Kohlhammer, 2007.

Sturlese, L., "Dietrich von Freiberg", in A. Brungs, V. Mudroch, P. Schulthess (eds), Die Philosophie des Mittelalters, vol. 4. 13. Jahrhundert, Basel, Schwabe, 2017.

Torrell, J.-P., "Le savoir théologique chez les premiers thomistes", in Revue thomiste 97(1997), p. 9-30.

Torrell, J.-P., Recherches thomasiennes. Études revues et augmentées, Paris, Vrin, 2000.

Wippel, J., The Metaphysical Thought of Godfrey of Fontaines. A Study in Late Thirteenth-Century Philosophy, Washington, D.C., The Catholic University of America Press, 1981. 